\title{
Present-day crustal deformation along the El Salvador Fault Zone from ZFESNet GPS network
}

Alejandra Staller ${ }^{a, *}$, José Jesús Martínez-Díaz ${ }^{b, c}$, Belén Benito ${ }^{a}$, Jorge Alonso-Henar ${ }^{b, d}$, Douglas Hernández ${ }^{\mathrm{e}}$, Román Hernández-Rey ${ }^{\mathrm{a}}$, Manuel Díaz $^{\mathrm{e}}$

a. Dpto. de Ingeniería Topográfica y Cartografía, Universidad Politécnica de Madrid. Madrid, Spain

b. Departamento de Geodinámica, Universidad Complutense de Madrid, Madrid, Spain

c. IGEO, Instituto de Geociencias, UCM-CSIC, Madrid, Spain

d. CEI Campus Moncloa, UCM-UPM, Madrid, Spain

e. Gerencia de Geología, Dirección General del Observatorio Ambiental, Ministerio de Medio Ambiente y Recursos Naturales., El Salvador. ahernandez@marn.gob.sv

(*) Corresponding author: a.staller@upm.es; Dpto. de Ingeniería Topográfica y Cartografía, Universidad Politécnica de Madrid. Campus Sur, Autovía de Valencia km. 7, 28031 Madrid, Spain. +34913366487

\section{Abstract}

This paper presents the results and conclusions obtained from new GPS data compiled along the El Salvador Fault Zone (ESFZ). We calculated a GPS-derived horizontal velocity field representing the present-day crustal deformation rates in the ESFZ based on the analysis of 30 GPS campaign stations of the ZFESNet network, measured over a 4.5 year period from 2007 to 2012 . The velocity field and subsequent strain rate analysis clearly indicate dextral strike-slip tectonics with extensional component throughout the ESFZ. Our results suggest that the boundary between the Salvadoran forearc and Caribbean blocks is a deformation zone which varies along the fault zone. We estimate that the movement between the two blocks is at least $\sim 12 \mathrm{~mm} \mathrm{yr}^{-1}$. From west to east, this movement is variably distributed between faults or segments of the ESFZ. We propose a kinematic model with three main blocks; the Western, Central and Eastern blocks delimited by major faults. For the first time, we were able to provide a quantitative measure of the present-day horizontal geodetic slip rate of the main segments of ESFZ, ranging from $\sim 2 \mathrm{~mm} \mathrm{yr}^{-1}$ in the east segment to $\sim 8 \mathrm{~mm}$ $\mathrm{yr}^{-1}$, in the west and central segments. This study contributes new kinematic and slip rate 
data that should be used to update and improve the seismic hazard assessments in northern Central America.

Key Words: Active tectonics; GPS; Geodynamics; Crustal deformation; El Salvador Fault Zone; Central America volcanic arc.

\section{Introduction.}

El Salvador is located in northern Central America, at the Pacific Ocean margin of the Caribbean plate, in the western margin of the Chortis block (Rogers et al., 2007) (Fig. 1). Along the El Salvador Pacific coast, convergence between the Cocos and Caribbean plates is accommodated by a combination of $73 \mathrm{~mm} \mathrm{yr}^{-1}$ of northeast-directed Cocos Plate subduction (DeMets et al., 2010) and $\sim 14 \mathrm{~mm} \mathrm{yr}^{-1}$ of northwestward trench-parallel motion of the Central American forearc (CAFA) (Fig. 1) (Turner et al., 2007; LaFemina et al., 2009; Correa-Mora et al., 2009; Alvarado et al., 2011; Franco et al., 2012; Kobayashi et al., 2014). This process works under a setting of low degree of coupling across the Middle America subduction zone (e.g. Álvarez-Gómez et al., 2008; Correa-Mora et al., 2009; LaFemina et al., 2009; Franco et al., 2012; Geirsson et al., 2015). Therefore, the causes of the northwestward trench-parallel motion of the CAFA are nowadays a topic of discussion. There are three main driving forces suggested in the literature for CAFA motion: (1) oblique convergence between the Cocos and Caribbean plates (DeMets, 2001); (2) Cocos Ridge collision offshore Costa Rica (LaFemina et al., 2009), which forces the northwestward lateral escape of the CAFA, driving the Nicaraguan forearc to the northwest which pushes the Salvadoran forearc; (3) pull on the CAFA western edge, caused by the pinning of the CAFA with the North American plate at the diffuse triple junction (Lyon-Caen et al., 2006; Álvarez-Gómez et al., 2008; Franco et al., 2012), which would cause the westward dragging of the CAFA due to North American plate motion. This idea highlights the importance of the weakness area along the volcanic arc in the geodynamic evolution of the Chortis block (Burkart and Self, 1985; Malfait and Dinkelman, 1972; Rogers et al., 2007), explaining the extensional structures formed in both the Salvadoran and Nicaraguan forearcs (e.g. Álvarez-Gómez et al, 2008). Associated with these processes, destructive earthquakes within the Salvadoran volcanic arc have occurred periodically over the past century (White, 1991; White and Harlow, 1993) and offshore along the Cocos Plate subduction interface (e.g. Benito et al., 2004; Geirsson et al., 
2015) (Fig. 2). In the last 100 years El Salvador has suffered at least 11 destructive earthquakes that have caused more than 3,000 victims (Bommer et al., 2002), underlining the importance of better understanding their sources and causes.

According to Canora et al., 2010, the last destructive earthquake in El Salvador, the 13 February 2001, Mw 6.6 earthquake (Fig. 2), was caused by a tectonic rupture on one of the segments of the El Salvador Fault Zone (ESFZ) (Martínez-Díaz et al., 2004; Corti et al., 2005). The ESFZ is thought to be responsible for frequent damaging earthquakes (e.g. 1951, $M_{s} 5.9$; 1965, $M_{s}$ 6.3; 1986, $M_{s}$ 5.4;) in El Salvador (Martínez-Díaz et al., 2004; Canora et al., 2010). Some authors (e.g. Álvarez-Gómez, 2009; Alvarado et al., 2011; Franco et al., 2012) suggest that this fault system could be accommodating the $\sim 14 \mathrm{~mm} \mathrm{yr}^{-1}$ trench-parallel strike-slip displacements due to the eastward movement of the CAFA relative to the Caribbean plate.

In the recent decades, several studies have tried to quantify the kinematics of the principal structures in Central America that are accommodating active deformation, as well as to understand the factors and tectonic forces that control this deformation (e.g. DeMets, 2001; DeMets et al., 2007; Álvarez-Gómez et al., 2008; Correa-Mora et al., 2009; LaFemina et al., 2009; Alvarado et al., 2011; Franco et al., 2012; Kobayashi et al., 2014; Alonso-Henar et al., 2015).

So far, geodetic studies carried out in northern Central America (Lyon-Caen et al., 2006; DeMets et al., 2007; Turner et al., 2007; LaFemina et al., 2009; Alvarado et al., 2011; Franco et al., 2012; Kobayashi et al., 2014) have mainly focused on understanding the regional tectonics of this region. The existing geodetic data in El Salvador did not allow the carrying out a detailed analysis of the kinematics of the active faults associated with the Salvadoran volcanic arc. In consequence, in this paper we show the first detailed results of a new geodetic GPS network established in El Salvador that allows us not only to refine previous results but also to complement the data set in El Salvador. From the obtained GPS velocity field, we quantify current crustal deformation rates in the area in order to estimate the current activity and behavior of the different segments of the El Salvador Fault Zone (ESFZ) (Fig. 2). These new data will be very useful for improving the seismic hazard assessments in the region.

\section{Seismotectonic setting.}

\subsection{Active faults - The ESFZ structure.}


The El Salvador Fault Zone (ESFZ) is an active, c. $150 \mathrm{~km}$ long and $20 \mathrm{~km}$ wide, dextral strikeslip fault zone within the El Salvador Volcanic Arc striking $N 90^{\circ}-100^{\circ} \mathrm{E}$ (Martínez-Díaz et al., 2004; Corti et al., 2005). It is composed of several larger E-W to ESE-WSW strike-slip faults with lengths ranging 20-30 km and secondary N-S and NNW-SSE normal and oblique-slip faults that accommodate deformation between larger faults. No evidence of pure strike slip movements is observed in these faults. The ESFZ has been divided into five segments according to structural, geometric and kinematic criteria which are, from west to east: the Western, San Vicente, Lempa, Berlin and San Miguel segments (Canora et al., 2012 and Fig. 2).

The main faults of the ESFZ have strikes ranging $N 90^{\circ}-110^{\circ} \mathrm{E}$ and dips of $70^{\circ}$. These faults are interpreted as part of several inherit graben structures formed during a previous extensional phase, that are reactivated under a younger strike slip regime (Canora et al., 2014b; AlonsoHenar et al., 2014). According to these authors the main E-W faults that control the larger segments were formed during the regional roll-back process affecting the subducting Cocos plate during Upper Pliocene to Pleistocene that induced the formation of large graben structures in Nicaragua and smaller and discontinuous graben structures in El Salvador (Weinberg, 1992). The deformation in the intersegment regions is dominated by distributed smaller faults with strong normal component bounding pull-apart basins that link the inherit overlapping grabens (Alonso-Henar et al., 2014).

Several authors had quantified slip rates of some faults within the ESFZ. They provided slip rates based on morphotectonic analyses and offsets in the Quaternary drainage network. For example, Corti et al. (2005) proposed a slip-rate of $\sim 11 \mathrm{~mm} \mathrm{yr}^{-1}$ for the El Triunfo fault. However, Alonso-Henar et al. (2014), based on a morphometric analysis, proposed horizontal slip rates of $4.6 \mathrm{~mm} \mathrm{yr}^{-1}$ for this same fault. Canora et al. (2012; 2014b) calculated a slip rate for the central-east section of the ESFZ (San Vicente Fault) of $\sim 4 \mathrm{~mm} \mathrm{yr}^{-1}$ from

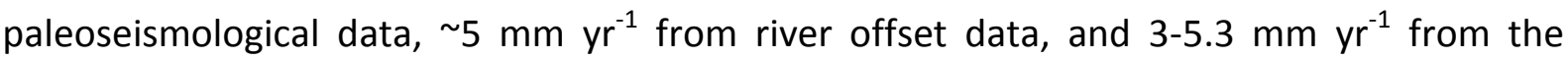
offsets affecting older volcanic morphologies that are indicative of long term slip rates.

The ESFZ flanks a longitudinal morphological depression, produced by the extensional tectonics describe above, where several active volcanoes (Izalco, Santa Ana, Coatepeque, San Salvador, Ilopango, San Vicente, San Miguel, Berlin, etc. (Figs. 1 and 2)) are located. These volcanoes influence the local style of faulting (e.g. Cailleau et al., 2007; Holohan et al., 2008; Mathieu et al., 2011) and must be considered in the interpretation of GPS velocities. 


\subsection{Instrumental and historical seismicity.}

Traditionally, the seismicity in this area has been divided into two kinds of earthquakes (White, 1991 and White and Harlow, 1993): large earthquakes related to subduction processes and moderate magnitude earthquakes related to the crustal faults within the volcanic arc (Fig. 2). However, Canora et al. (2014a) proposed that this division could not be so simple, and the ESFZ could have been the source of historical earthquakes with magnitudes over $M_{w}>7$, such as the March $6^{\text {th }} 1719 M_{s} 7.2$ El Salvador event (Peraldo and Montero, 1999), traditionally related to the subduction interface.

The largest historical earthquakes related with subduction processes are linked to outer rise normal faults and Caribbean-Cocos subduction interface events (Ambraseys and Adams, 1996; Guzmán-Speziale et al., 2005). In El Salvador, the subduction interface presents low coupling (Álvarez-Gómez et al., 2008; Correa-Mora et al., 2009; LaFemina et al., 2009; Rodríguez et al., 2009; Kobayashi et al., 2014), which accounts for the higher frequency of outer-rise normal fault earthquakes. The outer-rise earthquakes are generated on the inherited structures related to seafloor spreading fabric during the subducting plate bending (White and Harlow, 1993; Álvarez-Gómez et al., 2012). The most recent example of such an event is the January $13^{\text {th }} 2001 M_{w} 7.7$ earthquake (Bommer et al., 2002) that produced several catastrophic landslides in El Salvador. In Martinez-Diaz et al. (2004) it is shown how normal faulting of the Middle American subduction zone trigger destructive earthquakes in strike-slip faults in the Salvadoran volcanic arc. According to this study, the Coulomb failure stress (CFS) change produced by the January $13^{\text {th }} 2001$ subduction event on planes parallel to the El Salvador Fault Zone triggered the February $13^{\text {th }} M_{w} 6.6$ ESFZ earthquake (Canora et al., 2010) (Fig. 2). However, on $27^{\text {th }}$ of August 2012 the last major megathrust earthquake $\left(M_{w}\right.$ 7.3) occurred offshore El Salvador (Geirsson et al., 2015). Until this event, the region offshore was considered a seismic gap for nearly a century.

A second major source of seismicity is related to the local fault system that extends from west to east along the volcanic chain. Historically, the majority of the events in this source have moderate magnitudes $\left(5.5<\mathrm{M}_{\mathrm{w}}<6.8\right)$ and shallow depths $(\mathrm{h}<20 \mathrm{~km})$. The February $13^{\text {th }} 2001 M_{w} 6.6$ event is representative of these larger upper plate earthquakes (Bommer et al., 2002; Benito et al., 2004). These events contribute significantly to the seismic hazard and risk in the region, and historically have caused more deaths and damage than large 
earthquakes in the subduction zone (White and Harlow, 1993), mainly because of their short recurrence intervals, shallow depths, and proximity to population centers.

The 11 destructive shallow crustal earthquakes that have occurred in El Salvador during the last century are aligned along the volcanic arc (see Fig. 1b in Canora et al., 2010) (see Benito et al. (2010), and references therein). Four reliable focal mechanisms are available for the more recent major events of 1951, 1965, 1986, and February 2001 (Fig. 2) (Martínez-Díaz et al., 2004, and references therein). They are all strike-slip events with one of the nodal planes oriented east-west, parallel to the volcanic arc. The San Vicente segment was the only segment involved in the February $13^{\text {th }} 2001 M_{w} 6.6$ earthquake (Canora et al., 2012). However, recent paleoseismic studies suggest that the ESFZ may be capable of generating large magnitude earthquakes $\left(M_{w}>7.0\right)$ if more than one segment is involved in an event (Canora et al., 2012), as they suggest occurred during the 1719 earthquake.

Besides tectonic seismicity, the seismicity of volcanic origin in certain sectors of the ESFZ is also important. This seismicity may indicate deformations controlled by volcanic activity.

\subsection{Previous geodetic studies.}

The first geodetic measurements in northern Central America began in the late 1990's (Dixon et al., 1991) in order to determine the current movement of the Caribbean plate. Since then, several authors have developed new measures for different purposes and location (Lyon-Caen et al., 2006; Turner et al., 2007; LaFemina et al., 2009; Alvarado et al., 2011; Franco et al., 2012; Kobayashi et al., 2014). The first geodetic studies that indicate the CAFA motion began in Costa Rica (e.g. Lundgren et al., 1999). However the idea of forearc sliver transport goes back to earlier seismic studies (e.g. Molnar and Sykes, 1969) and later by McCaffrey (1992; 1996) and DeMets (2001).

The first relevant geodetic measurements in northern Central America were reported by Lyon-Caen et al. (2006) in order to describe the faults kinematic in the North America, Caribbean and Cocos plates triple junction area and also to understand the complex regional active tectonics. Later Franco et al. (2012) increased the Lyon-Caen et al. (2006) data set in Guatemala, extending the study area with new GPS measurements in Chiapas (southern Mexico) and El Salvador. These studies document a rate of up to $22 \mathrm{~mm} \mathrm{yr}^{-1}$ for the motion of the North America and Caribbean plates relative to eastern Guatemala, mostly accommodated across the Motagua fault. As a consequence, the western tip of the Caribbean plate deforms internally, with up to $9 \mathrm{~mm} \mathrm{yr}^{-1}$ of east-west extension. Franco et 
al. (2012) suggest that up to $15 \mathrm{~mm} \mathrm{yr}^{-1}$ of dextral motion can be accommodated across the volcanic arc in El Salvador and southern Guatemala, which could mark the northern boundary of an independent forearc sliver (CAFA), pinned to the North American plate. Several authors (e.g. Álvarez-Gómez et al., 2008; Correa-Mora et al., 2009; LaFemina et al, 2009; Franco et al., 2012; Geirsson et al., 2015) confirm the weak coupling at the CocosCaribbean subduction interface offshore Guatemala, El Salvador and Nicaragua.

Alvarado et al. (2011) combine geodetic, structural and paleomagnetic data from southern Honduras, El Salvador and Nicaragua to describe the motions of the Salvadoran and Nicaraguan forearcs and to determine the location and style of faulting across the Gulf of Fonseca (Fig. 1) where the volcanic arc changes its trend and suffer an offset between El Salvador and Nicaragua. Using finite-element modeling they show that both the Nicaraguan and Salvadoran forearcs move westward northwestward, parallel to their respective trenches, at $15 \pm 2 \mathrm{~mm} \mathrm{yr}^{-1}$ in a Caribbean plate reference frame. They suggest that this similar motion of the two forearc slivers is consistent with the hypothesis that the Nicaraguan forearc pushes the Salvadoran forearc to the northwest, possibly driven by northwestward lateral escape of the Central America forearc sliver forced by the Cocos Ridge collision offshore Costa Rica, as has been proposed by previous authors (LaFemina et al., 2009). Another important result of the latter is the definition of $\sim 60-\mathrm{km}$-wide extensional zone with E-W elongation in the Gulf of Fonseca and eastern El Salvador that may be accompanied by bookshelf faulting (e.g. LaFemina et al., 2002).

\section{GPS data and processing.}

\subsection{ZFESNet GPS Network.}

The ZFESNet geodetic network was established in 2007 to quantify current crustal deformation rates in the El Salvador Fault Zone. The project was developed by the Technical University of Madrid (UPM) with collaboration of the Servicio Nacional de Estudios Territoriales (SNET) of El Salvador from 2007 to 2012. The ZFESNet (Staller et al., 2008) consists of 30 GPS campaign stations, 23 new and 7 existing (Alvarado et al., 2011), covering $200 \mathrm{~km}$ long and $70 \mathrm{~km}$ wide area, from the Coatepeque caldera to the Gulf of Fonseca with a distribution as homogeneous as possible over the ESFZ (Fig. 3). Geological, geodetic and logistical criteria were taken into account in the design and implementation of the network. We tried to locate the new stations in safe places with the possibility of vigilance during the observation; although for this purpose we also had the support of the El Salvador Army. Due 
to operational and cost reasons, the monumentation of the new stations consists of a stainless steel nail anchored mostly on stable rock, excepting two sites anchored on concrete, which guarantee reoccupation after a time span (Dixon et al., 2000).

Blewitt and Lavallée (2002) established that to obtain accurate conclusions from GPS coordinate time series it is necessary to cover a period of at least four years in episodic surveys or 2.5 years of continuous GPS data. In our case, the results are based on four campaigns conducted in 2007, 2008, 2010 and 2012, covering a period of 4.5 years. In general, episodic campaigns should be conducted in the same months to minimize seasonal effects. However, due to logistical problems, the 2007 and 2008 campaigns were conducted in November, and the 2010 and 2012 campaigns in April and May respectively. Some significant differences were detected in the vertical component repeatabilities obtained in the campaigns conducted in different seasons; the October and November campaigns (2007 and 2008) obtained appreciably better results than the April-May ones (2010 and 2012) (see Section 3.2). All sites were usually occupied by more than two sessions during each campaign, with session lengths of $18-24 \mathrm{~h}$ at most stations. We rejected short observing sessions (less than 7 hours) (Wallace et al., 2004). The requirement of constant security surveillance of the equipment limited the possibility of longer sessions. The sampling interval for data logging was 30s. All the campaign measurements were made using four Trimble 5700 GPS receivers and Zephyr Geodetic antennas, except for a handful of sites that were occupied in the 2008 campaign with one Trimble R7 receiver with the Zephyr Geodetic antenna. We use three types of antenna mounts (Fig. 4): (i) tripod with tribrach and optical plummet (used only in 2007 campaign), (ii) 1.127 m levelled fixed-high pole (Fernández et al., 2004) (used in 2008, 2010 and 2012 campaign) and (iii) $0.550 \mathrm{~m}$ fixed-height spike mount (used in 2007, 2008, 2010 and 2012 campaign). No significant differences were detected in the repeatabilities obtained with the different types of antenna mounts (see Section 3.2).

\subsection{GPS data processing.}

We processed data from 45 GPS stations. Among these were 30 GPS episodic sites (eGPS), belonging to the ZFESNet network. We also used 5 continuous GPS stations (cGPS); 4 located in El Salvador (AIES, CNR1, SNJE, VMIG) currently belonging to UNAVCO, and one in Honduras (TEG1). Stations AIES, CNR1, SNJE, VMIG and TEG1 are continuously recording sites installed in 2007, except CNR1 that was installed in 2008. However, since all the data from these stations were not available at the time of the study, we treated them as eGPS 
stations, analyzing data from the same days as the 2007, 2008, 2010 and 2012 ZFESNet surveys.

In addition, to link the survey results to the global reference frame ITRF2008 (International Terrestrial Reference Frame 2008) (Altamimi et al., 2012), we included 5 cGPS stations distributed throughout Central America (CHET, ELEN, GUAT, MANA and SSIA): four belonging to IGS (Dow et al., 2009) and one to CORS (Snay and Soler, 2008) networks. These CGPS were selected according to the availability of data on the dates of the campaigns, the proximity and the best possible geometric configuration.

GPS data were processed using Bernese 5.0 software (Dach et al., 2007), with double difference phase observable. The IGS precise orbit and Earth's orientation parameters were kept fixed and the absolute elevation-dependent phase center corrections, provided by IGS were applied. GPS data modeling included elevation-dependent phase center corrections (IGS absolute calibrations) and the FES2004 (Letellier et al., 2004) ocean tide loading model. The tropospheric effect was modelled with the a prior dry-Neill (Neill, 1996) model fulfilled by the estimation of zenith delay corrections at 1-h intervals at each site using the wet-Neill mapping function. The ambiguity resolution is based on the Quasi-lonosphere-Free (QIF) baseline-wide analysis. We estimated each daily solution in a loosely constrained reference frame. Constraints for the realization of the chosen reference frame were only imposed a posteriori. The coordinates of the IGS stations were constrained (NNT-No Net Translation option) to their ITRF2008 values.

The program ADDNEQ2 in the Bernese 5.0 software was developed to compute multisession solutions from the statistically correct combination of a set of single-session solutions. It can also be applied to estimate the station velocity if the data set covers a long time span. The normal equations (NEQs) of single session solutions for a campaign are first combined to create a campaign solution. An annual survey campaign in the ZFESNet usually spans 20-25 days. The multi-year campaign solutions are then combined to estimate station velocities. The ITRF2008 coordinates and velocities of the ZFESNet stations were obtained using constraints on the coordinates and velocities of the 5 fiducial stations (with asterisk in Table 1).

Formal errors derived from Bernese are not realistic, therefore the obtained precisions are overly optimistic and do not correctly represent the estimated parameter errors (Kashani et al., 2004). The uncertainties deduced from the daily repeatability are more realistic than the 
formal statistical Root Mean Square (RMS) error. We estimated average horizontal baseline repeatability (scatter about the root mean square value) of the order of a few millimeters for most local baselines (<150 km) for all campaigns, with mean values of $2.0 \mathrm{~mm}, 2.0 \mathrm{~mm}$ and $7.7 \mathrm{~mm}$ for the east, north and up components, respectively. We also estimated the daily repeatability of the computed station coordinates from each campaign, with values ranging from $0.5 \mathrm{~mm}$ to $3.5 \mathrm{~mm}$ for the horizontal components and about a mean of $8 \mathrm{~mm}$ in the vertical component. However, we noticed a significant difference $(\sim 3 \mathrm{~mm})$ in the vertical repeatability between the results of 2007 and 2008 campaigns, conducted in OctoberNovember, and 2010 and 2012 campaigns, conducted in April-May. This could be due to a seasonal variability. Details of the processing and coordinate results are given in Staller (2014).

We also deduced appropriate scaling factors for the formal velocity errors in order to arrive at realistic accuracies. Scaling factors for formal velocity errors of campaign stations, originating from the ADDNEQ2-solution, were computed by comparing these formal errors with the accuracies deduced from the time series analysis. We obtained a factor of 12 for the horizontal velocity errors. This leads to a mean uncertainty on the horizontal velocities of $\pm 1.8 \mathrm{~mm} \mathrm{yr}^{-1}$. All accuracies given in the following sections are scaled using the corresponding factors. An exception are the stations with a register interval lower than 4.5 years, i.e. stations located in the northwest (MNGO, TACA, GUAY, PLAY), and VIEJ, RIOG stations observed from 2008 to 2012. Such stations have a greater velocity uncertainty, with a mean value of $2.4 \mathrm{~mm} \mathrm{yr}^{-1}$ in the east and north component.

In order to interpret the GPS results in terms of regional deformation associated with the ESFZ, we considered the coseismic deformation resulting from regional earthquakes which occurred in the 2007-2012 period, with $M_{w}>6.0$ and depth $<60 \mathrm{~km}$. It should be noted that the data were recorded before to the 2012 August $27 \mathrm{M}_{\mathrm{w}} 7.3 \mathrm{El}$ Salvador subduction zone earthquake (Geirsson et al., 2015). Therefore, we only took into account the $M_{w}=7.32009$ May 28 earthquake which occurred on the Swan Islands fault near Roatan island off the north coast of Honduras (Fig. 1). We estimated the displacement at our sites induced by this earthquake from the model published by Graham et al. (2012). Differences between corrected and uncorrected velocities are lower than $2 \mathrm{~mm} \mathrm{yr}^{-1}$, practically within the estimated uncertainties of the GPS velocities. In the following text we use these corrected velocities. 
Velocities in ITRF2008 were transformed into a Caribbean fixed reference frame (Fig. 3) by rotating them about the CA/ITRF2008 pole $\left(36.96^{\circ} \mathrm{N},-100.47^{\circ} \mathrm{E}, 0.263^{\circ} / \mathrm{Ma}\right)$ determined by DeMets (personal communication, 2013), using 18 stations throughout the Caribbean plate. This pole differs significantly from those obtained by Altamimi et al. (2012), mainly due to the difference in the number of stations used and their distribution within the Caribbean plate. Propagation of the formal uncertainties in the Caribbean-ITRF2008 angular velocity into the velocity uncertainties for the GPS stations in Central America typically increases those uncertainties by $0.2 \mathrm{~mm} \mathrm{yr}^{-1}$ or less (Alvarado et al., 2011), too small to matter for our analysis. Fig. 3 and Table 1 show our present-day velocity field in a Caribbean reference frame. The results are derived using the assumption of constant velocities between the five years (2007-2012). In Fig. 3, the 65\% confidence ellipse is plotted at the tip of each velocity vector.

\section{Results.}

\subsection{GPS velocities.}

The most prominent feature of our velocity field in a Caribbean reference frame (Fig. 3) is the dominant motion trending $\sim \mathrm{N} 290^{\circ} \mathrm{E}$, practically perpendicular to the convergence trend between the Cocos and Caribbean plates at N20 $\mathrm{E} \pm 2^{\circ}$ (DeMets et al., 2010 and Kobayashi et al., 2014). We observed a notable decrease of the velocities towards the north, reaching values close to zero at stations located in the backarc. Velocities increase southward, reaching the maximum values in the forearc and near the Salvadoran coast, with rates of up

to $\sim 12 \mathrm{~mm} \mathrm{yr}^{-1}$ (AIES station). Within this group some stations exhibit anomalous behavior, such as LSSJ (faster motion toward east than other neighboring stations) and CNR1 (southward motion) (blue vectors in Fig. 3). A repeatability analysis of the ITRF2008 coordinates and temporal series of the LSSJ station (see Fig. S1 in supplementary material) show inadequate values in the east component at this site. These results could be due to causes such as errors during measurement, monumentation instability or local non-tectonic deformation. It is necessary to carry out more measurements to verify the velocity pattern obtained from 2007 and 2012 at this station. For this reason, we do not consider the LSSJ velocity neither in the final velocity field, nor in the following analysis and discussion. CNR1 velocity is similar to other velocities in the Salvadoran forearc but with a SW trend. We analyzed the time series of CNR1 (see Fig. S1 in supplementary material) and observed a change in the trend of the north component after the 2010 campaign (May 2010). This 
station registered a southward movement of $\sim 5 \mathrm{~mm} \mathrm{yr}^{-1}$ between May 2010 and May 2012. We also verified a change in the vertical component with an uplift in the same period of about $20 \mathrm{~mm}$. We tried to analyze the possible causes of this change in the behavior of CNR1, attributing that it is possibly produced by a period of volcanic unrest of the San Salvador volcano (which is located $10 \mathrm{~km}$ northward). The increase of seismicity to the north of this station in this time period would support this interpretation (see Fig. S2 in supplementary material). In the following we use the velocity of CNR1 estimated with the positions in the period 2008- 2010, removing the 2012 position which is affected by the anomalous movement (black vector showed in Fig. 3).

We identified three main groups of stations with approximately homogeneous behavior (Fig. 3): (1) The group of stations located in the Salvadoran backarc is characterized by the smallest velocities, between 2 and $4 \mathrm{~mm} \mathrm{yr}^{-1}$, and a predominant orientation of $\mathrm{N}^{\circ} 305 \mathrm{E}^{\circ}$ which indicates that they belong to the Caribbean plate. The high uncertainties at GUAY, MNGO and RIOG stations that show velocities rotated with respect to the dominant orientation of the group should be noted. (2) The group formed by the stations located in the forearc shows velocities practically perpendicular to the Coco/Caribe convergence with an orientation of $\mathrm{N}^{2} 80^{\circ} \mathrm{E}$, reaching values of up to $12 \mathrm{~mm} \mathrm{yr}$. This value almost totally represents the Salvadoran forearc movement, although it is slightly lower than that reported by other authors for the El Salvador forearc sliver, $14 \mathrm{~mm} \mathrm{yr}^{-1}$ (e.g. Correa-Mora et al., 2009; Alvarado et al., 2011; Kobayashi et al., 2014). Some exceptions are BT10 and USUL, which are moving in a more westward direction $\left(\sim 270^{\circ}\right)$ than the dominant motion of the group. This difference could be caused by the proximity to the Berlin and Usulután active volcanic areas, recording movements related to volcanic activity. A significant increase of the rates from east to west is also observed in this group of stations, with velocities of $\sim 5 \mathrm{~mm}$ $\mathrm{yr}^{-1}$ in stations located near the Gulf of Fonseca (SAIN and AMAT), clearly lower than the velocities of the western stations (AIES, VIEJ and NONU), with rates up to $12 \mathrm{~mm} \mathrm{yr}^{-1}$. (3) The group formed by stations located in the central part of El Salvador, near the Salvadoran

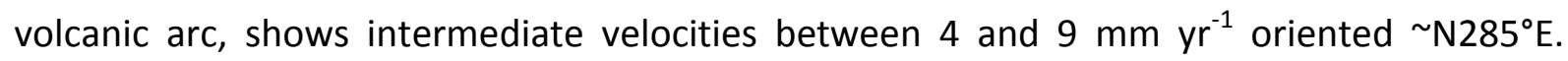
These stations are located within the ESFZ area of influence, accommodating part of the deformation associated with this structure. It should be noted that SVIC and CARM velocities, located close to the San Vicente Fault, which was responsible for the February 
$13^{\text {th }} 2001 M_{w} 6.6$ earthquake, show an unexpected increase in the parallel and normal component velocities.

\subsection{GPS velocity profiles.}

To better quantify the velocities and understand how the deformation is accommodated within the ESFZ, we analyze the velocities projected along five profiles perpendicular to the main segments of the ESFZ (Figs. 2, 3 and 5a-e). Fig. 5a-e depicts the site's fault-parallel (black dots) and fault-normal (triangles) velocity components plotted against their distance to the fault traces for the five profiles. We use the geometry and location of the main fault traces of Canora et al., 2012.

Profile A-A' (Fig. 3) is perpendicular to the West segment and covers the Central Graben of El Salvador, limited to the north by the Guaycume fault (Fig. 2). The fault-parallel velocities (black dots in Fig. 5a) show a right lateral motion of $11 \pm 3 \mathrm{~mm} \mathrm{yr}^{-1}$ between AIES and MNGO. This movement is mostly concentrated in Guaycume fault, with a repartition between the Guaycume fault to the north, with a right lateral slip rate of $9 \pm 3 \mathrm{~mm} \mathrm{yr}^{-1}$, and the southern faults of the Graben, with a smaller rate of $2 \pm 0.5 \mathrm{~mm} \mathrm{yr}$. The fault-normal velocities (triangles in Fig. 5a) show an extensional rate of up to $4 \pm 2.5 \mathrm{~mm} \mathrm{yr}^{-1}$ that could be associated with the Central Graben structure (Figs. 2 and 3).

Profile B-B' (Fig. 3) is perpendicular to San Vicente Segment (Fig. 2). The fault-parallel velocities (black dots in Fig. $5 \mathrm{~b}$ ) show a right lateral motion of $10 \mathrm{~mm} \pm 1 \mathrm{~mm} \mathrm{yr}{ }^{-1}$ across ESFZ, between AIES and CEGD. The movement is clearly concentrated in a band of less than $20 \mathrm{~km}$ around the San Vicente fault trace, which presumably is accumulating most of the elastic deformation. No significant motion normal to the fault is appreciated (triangles in Fig. $5 b)$.

Profile C-C' (Fig. 3) covers the Lempa segment in the central part of the ESFZ, going through the Lempa pull-apart basin (Corti et al., 2005) (Fig. 2). The fault-parallel velocities (black dots in Fig. 5c) show a right lateral motion of $9 \pm 2 \mathrm{~mm} \mathrm{yr}^{-1}$ across the Lempa pull-apart basin, between AIES and RIOG. The fault-normal velocities (triangles in Fig. $5 \mathrm{c}$ ) show an extensional component rate of $3 \pm 1.5 \mathrm{~mm} \mathrm{yr}^{-1}$.

Profile D-D' (Fig. 3) is perpendicular to the Berlin segment (Fig. 2). The fault-parallel velocities (black dots in Fig. $5 \mathrm{~d}$ ) show a right-lateral motion of $7.5 \pm 3.5 \mathrm{~mm} \mathrm{yr}^{-1}$, mainly accumulated in the Berlin segment, formed by the El Triunfo and Lolotique faults. BT10 station, located at the Berlin geothermal field, shows anomalous values, mostly in the 
parallel component. The fault-normal velocities (triangles in Fig. $5 \mathrm{~d}$ ) show a more complexity in the distribution of deformation in this area, mainly in the southern part of the profile.

Profile E-E' (Fig. 3) in the eastern end of the ESFZ (close to the Gulf of Fonseca) is perpendicular to the San Miguel Segment (Fig. 2). The movement occurs mainly in the southern part, between SAIN and JUCU, showing clearly that JUCU is not part of the rightlateral movement of the E-W fault zone. The fault-parallel velocities (black dots in Fig. 5e) show a right lateral motion of $3 \pm 2 \mathrm{~mm} \mathrm{yr}^{-1}$ between SAIN and OSIC, that could be associated with the right lateral motion of the San Miguel Segment. There is a parallel component rate motion of $5 \pm 2.5 \mathrm{~mm} \mathrm{yr}^{-1}$ between JUCU and SAIN, which could be associated with other extensional structures (discussed below). No significant motion in the normal component of velocity (triangles in Fig. 5e) is appreciated.

\subsection{Strain rate calculation.}

In contrast to the displacement data, the strain rate tensor is independent of the reference frame. The strain rate field reveals local strain accumulation rates and their possible connection to seismic hazard potential (Ward, 1994). We calculated the velocity gradient tensor from the horizontal velocity field from ZFESNet GPS velocities, based on the formulation of Feigl et al. (1990). For that, a Delaunay triangulation method was used and displacements at vertex of triangles were assumed homogeneous within properly formulated network triangles. Afterwards the velocity gradient was used to calculate strain and rotation rates within the network. From these parameters, we also calculated dilatation $(\bar{\varepsilon})$ and maximum shear strain rates $(\dot{\gamma})$ and their directions.

The horizontal principal strain rate axes $\left(\dot{\varepsilon}_{1}\right.$ and $\left.\dot{\varepsilon}_{2}\right)$ and dilatation $(\bar{\varepsilon})$ are shown in Fig. 6 . In general, there is a predominance of positive dilatation along the ESFZ that must be related to an extensional deformation of the crust. From here we refer to the positive dilatation as "extension" and negative dilatation as "shortening". The maximum extension rate is $0.68 \pm$ $0.16 \mu$ strain $\mathrm{yr}^{-1}$ while the maximum shortening rate is $0.41 \pm 0.22 \mu$ strain $\mathrm{yr}^{-1}$. The orientation of extension and shortening axes is mostly NE-SW and WNW-ESE, respectively, and is oblique to the traces of the ESFZ as expected. The highest extension rates are located in the eastern part of the Lempa River (Berlin segment), between the Berlin, Usulutan and San Miguel volcanoes, which suggests that this extension could at least partly be associated with volcanic activity. Similarly, in the Western segment, between the Ilopango and Coatepeque Calderas, there is also a predominant extension, with a maximum extension 
rate of $0.33 \pm 0.14 \mu$ strain $\mathrm{yr}^{-1}$ and orientation ENE-WSW. Here the deformation area is wider, generating a tectonically depressed area, coinciding with the Central Graben. The strain rates decrease significantly to the east, with mean values $\sim 0.11 \mu$ strain $\mathrm{yr}^{-1}$ in San Miguel segment and southeast of the ESFZ, and similar rates of extension and shortening. There is a significant change in the orientation of the extensional component in the southeast, with an average azimuth of $\sim 80^{\circ}$, which confirms the $\mathrm{E}-\mathrm{W}$ extension in this area (Jucuaran-Intipuca Range). In the central area of the ESFZ (San Vicente and Lempa segments), the strain rate is concentrated mainly in the Lempa pull-apart. Here, the shortening rate is greater than in the remainder of the fault zone. However, the extension predominates, with a maximum rate of $0.31 \pm 0.14 \mu$ strain $\mathrm{yr}^{-1}$. The predominant orientation of the extensional axes is also ENE-WSW. This distribution of strain rates clearly corresponds with the extensional inner faults of the pull-apart and strike-slip bounding faults.

Dilatation rate $(\overline{\dot{\varepsilon}})$ is calculated summing the shortening and extension rates. There is a predominance of positive dilatation rates in ESFZ (Fig. 6), with a maximum of $0.72 \pm 0.13$ $\mu$ strain $\mathrm{yr}^{-1}$ to the east of the Lempa River, coinciding with the Berlin Volcanic Field (Fig. 2). The western segment of ESFZ, between Coatepeque and Ilopango Calderas, presents also positive dilatation rates with an average rate of $\sim 0.20 \mu$ strain $\mathrm{yr}^{-1}$, which is consistent with the predominance of an extensional component in this area. On the east and southeast of the ESFZ null dilatation rates are obtained. The maximum negative rate is obtained south of Berlin volcanic zone, with $-0.42 \pm 0.11 \mu$ strain $\mathrm{yr}^{-1}$. The lack of data near the Salvadoran shore makes this value difficult to confirm and analyze.

The maximum shear strain rate $(\dot{\gamma})$ is a measure of a maximum change in the angle between two line segments that were orthogonal in the undeformed state. Maximum values of $\dot{\gamma}$ are obtained around the central part of ESFZ (Fig. 7), along San Vicente, Lempa and Berlin Segments $\left(0.80 \pm 0.27 \mu\right.$ strain $\left.\mathrm{yr}^{-1}\right)$. Furthermore, the predominant orientation of the rightlateral shear planes of $\dot{\gamma}$ in this region $\left(\sim 110^{\circ}\right)$ is in good agreement with the ESFZ segment orientations (Fig. 7). To the east, the maximum shear strain is obtained along the faults close to the coast, with an average value of $\sim 0.20 \mu$ strain $\mathrm{yr}^{-1}$. Here the orientation of right-lateral shear planes changes from $\sim 110^{\circ}$ to $\sim 120^{\circ}$.

In terms of the rigid body deformation, there is a clear predominance of clockwise rotation (Fig. S3 in supplementary material) along the ESFZ, with a mean value of $\sim 6^{\circ} \mathrm{Myr}^{-1}$. The maximum value of up to $19^{\circ} \mathrm{Myr}^{-1}$ coincides with the Lempa pull-apart. 


\subsection{Elastic strain model.}

With the exception of some sites, in general, the fault-parallel velocities projected along the profiles (Fig. 5a-e) show the typical shape of interseismic loading on a locked fault zone. We thus adopt the model of Savage and Burford (1973) for the elastic two-dimensional deformation of an infinite vertical strike slip fault. The model is derived from the screw dislocation theory and assumes locking on the fault to depth (D) and slip (V) by a constant amount below of this depth (Vigny et al., 2003). This model is widely used to model geodetic strain due to co-seismic and/or interseismic deformation, such as surface deformation predicted for any slip distribution at depth (e.g. Vernant, 2015). The key model parameters are the far field velocity $V$ and the locking depth $D$. An accurate estimate of the far field velocity (V) requires GPS velocity data more than several locking depths away from the fault (> $50 \mathrm{~km}$ ), while an accurate estimate of the locking depth requires a high density of GPS velocity data within one-half locking depth of the fault (<6 km spacing) (Smith-Konter et al., 2011). However, the typical spacing of GPS velocity measurements along the ESFZ (Fig. 3 ) is only 10-15 km, extending up to $35 \mathrm{~km}$ away from the main fault traces. Because of sparse geodetic data of ZFESNet, the far field velocity field could not be estimated well, resulting in depth uncertainties of the order of 3-6 km.

Taking into account these limitations and following the model described above, we use a least square approach to invert simultaneously for the position of the fault, the locking depth and the velocity of the modelled fault for each profile. We assume that the geometry and location of modelled faults were constrained by published data (Canora et al., 2012).

The best fit elastic model parameters $(D, V)$ with the rms errors obtained for each modelled fault is given in Table 2. Fig. 5 shows the arctangent curve (in red) depicting the site's faultparallel velocity components plotted against their distance from the fault trace for each profile.

The best fit elastic model parameter to Guaycume fault (profile A-A', Fig. 5a) provides values of $\sim 8 \mathrm{~mm} \mathrm{yr}^{-1}$ and $\sim 5 \mathrm{~km}$ for far field velocity and locking depth, respectively. The parallel velocities of the AIES and SSIA sites are not considered in the best fit model. The AIES site is far from the modelled fault and could be registering movements of the southern part of the Central Graben. The parallel component of SSIA shows an anomalous behavior, with a value less than expected. Because of its location, it could be related with the local deformations of the San Salvador Metropolitan Area (Lexa et al., 2011). However, the low density of stations 
in this segment and the high uncertainty in the majority of the velocities make the results of this profile not very reliable, especially the value for the locking depth.

The best fit elastic model parameter for San Vicente fault (profile B-B', Fig. 5b) corresponds to a far field velocity of $\sim 12 \mathrm{~mm} \mathrm{yr}^{-1}$ and a fault plane locked at $\sim 8 \mathrm{~km}$ depth, which is consistent with the rupture dimension of the February 2001 earthquake (Kikuchi and Yamanaka, 2001). However, taking into account other studies (Canora et al., 2012) we considered that the far field velocity value obtained for the San Vicente fault by the model could be somewhat high. Also, it should be noted that SVIC and CARM velocities, sited close to the San Vicente fault trace, show a parallel component higher than expected in the model, and their parallel velocities do not fit the model. This could be related to the postseismic effects of the February 13th, 2001 earthquake, which would produce a small increase in the parallel component of these stations (Feigl and Thatcher, 2006), as well as in the normal component, similar to the observed velocities (Fig. 3). Another explanation is that the faults south of the San Vicente fault (not studied yet) could be accumulating part of movement that the model has attributed to the San Vicente fault. To check this, we model the fault without considering the AIES, NONU and VIEJ fault parallel velocities (blue curve in Fig. 5b). This way, we obtain a rate of $\sim 7 \mathrm{~mm} \mathrm{yr}^{-1}$ for the San Vicente fault. In this case the model fits the SVIC and CARM parallel velocities perfectly.

The best fit model to the Apastepeque fault (profile C-C', Fig. $5 c$ ), in the Lempa segment, considers a fault plane locked at $\sim 6 \mathrm{~km}$ depth, with a far field velocity of $\sim 8 \mathrm{~mm} \mathrm{yr}^{-1}$. It should be noted that the parallel components of stations located south of the pull-apart basin (AIES, VIEJ and NONU) are below the best fit curve associated with the Apastepeque fault. This makes evident the activity of the faults bounding the southern limit of the pullapart structure, which is according to other morphotectonic studies (Alonso-Henar et al., 2014).

In the Berlin segment (profile D-D', Fig. 5d) we obtained a fault plane locked at $\sim 9 \mathrm{~km}$ depth, with a far field velocity of $\sim 7 \mathrm{~mm} \mathrm{yr}^{-1}$. Because of the location of these stations, we do not consider the parallel velocities of the JUCU, PRUS and USUL sites in the model. These stations could be recording movement associated with other structures with N-S and NNWSSE trends in the southern part of the ESFZ. BT10 station, located in the Berlin geothermal field, shows anomalous parallel velocity, which is possibly due to local movement associated with volcanic activity, and it is not considered in the model. 
The best fit model for the San Miguel segment (profile E-E', Fig. 5e) provides a far field velocity of $\sim 2 \mathrm{~mm} \mathrm{yr}^{-1}$ and a locking depth of $\sim 4 \mathrm{~km}$. We do not use the JUCU parallel velocity to fit the model, because this station is not part of the right-lateral movement of the $\mathrm{E}-\mathrm{W}$ fault zone.

It should also be noted that the models and observed velocities never reach $0.0 \mathrm{~mm} \mathrm{yr}^{-1}$ at their northern end, in the back arc, leaving approximately $2 \mathrm{~mm} \mathrm{yr}^{-1}$ of unaccounted strain. We note that the furthest stations in the profiles are less than $35 \mathrm{~km}$ away from the main fault and they could still be registering the elastic strain associated with the modelled faults. Thus, additional stations further away from the fault $(>50 \mathrm{~km})$ would be needed to register the Caribbean plate movement alone.

\section{Discussion.}

The velocity field and strain rate calculations show clear evidence of on-going crustal deformation in the El Salvador Fault Zone (ESFZ), indicating right-lateral strike-slip kinematics with a varying extensional component and strain distribution along the fault zone. In this section we discuss the importance of these results and present our interpretation in terms of local and regional tectonics.

\subsection{Strain distribution along ESFZ.}

The orientation and magnitude of the principal strain rate axes (Figs. 6 and 7) and rotation rates (Fig. S3 in supplementary material) obtained by the inversion of the GPS data are in agreement with the regional studies of seismicity (Cáceres et al., 2005) and are consistent with the active tectonic regime in the area.

Principal strain rates and dilatations (Fig. 6) show three zones with distinct deformational behavior: (1) The western zone, between the Coatepeque and Ilopango Calderas, with $\left|\dot{\varepsilon}_{1}\right|>\left|\dot{\varepsilon}_{2}\right|$ and positive dilatation, is characterized by a predominance of tectonic extension, consistent with a transtensional regime, mainly through strike-slip faults with a normal component and N-S normal faults (Lexa et al., 2011; Canora, 2011). (2) The central area, between llopango Caldera and the Lempa River, where deformation is mainly concentrated in the Lempa pull-apart basin, and with a predominance of the strike-slip kinematics. The strain rates distribution clearly agrees with the strain rate distribution of a pull-apart basin (Petrunin and Sobolev, 2008). (3) The SE of the ESFZ is characterized by a lower strain rate, with $\left|\dot{\varepsilon}_{1}\right| \approx\left|\dot{\varepsilon}_{2}\right|$, and a rotation of shortening axes $\left(\dot{\varepsilon}_{2}\right)$ in N-S direction, confirming the E-W extension in this area. 
The obtained strain and dilatation rates confirm that deformation is distributed in the southern region from the Lempa River, concentrated around the faults that bound the Lempa pull-apart in the central zone and extending from the western zone of the ESFZ. Maximum extension and dilatation rates are obtained east of the Lempa River, with $\left|\dot{\varepsilon}_{1}\right|>\left|\dot{\varepsilon}_{2}\right|$, coinciding with the Berlin, Usulutan and San Miguel volcanic zone (Fig. 2), which suggests that part of this strain could be caused by volcanic activity.

There is a clear predominance of clockwise rotation (Fig. S3 in Supplementary material) in the area, which is consistent with the ESFZ dextral kinematics. Maximum values coincide with the Lempa pull-apart zone, suggesting that the dextral shear combines with the interaction of E-W and N-S faults to form tectonic blocks having a greater susceptibility to undergoing rotations about vertical axes.

The strain, dilatation and rotation rates estimated are very consistent with a transtensional dextral strike-slip fault kinematics. However, it should be noted that our results are obtained from an irregular distribution of stations, in which the southern and western zones have less information.

The strain distribution along ESFZ ratifies the transference of deformation from the narrower western and central segments of the ESFZ where strike-slip regimen dominates, towards extensional structures distributed in a wider area along the southeastern part of the fault zone. This area is dominated by a dense network of normal faults oriented N-S, NW-SE and NNW-SSE that are very evident in the digital elevation models (Canora, 2011) and limited mainly by strike-slip faults oriented WNW-ESE, which is consistent with the results obtained by Alvarado et al. (2011). This extensional structure is part of the Fonseca basin, a releasing structure which could be related to the transition of movement between the Nicaraguan and Salvadoran arcs.

\subsection{ESFZ kinematic model.}

Fig. 8 shows the kinematic model proposed for the ESFZ in this study schematically. Table 2 shows the estimated slip-rates (parallel and normal to the fault trace) to the main faults analyzed in this paper. In the proposed model, we define three main blocks; Western, Central and Eastern blocks delimited by major faults and for which we have estimated slip rates.

The Eastern block, in southeastern El Salvador, comprises the extensional area that includes the Jucuaran-Intipuca Range and the Gulf of Fonseca. This block is clearly bounded on the 
north by the Berlin and San Miguel segments with dextral strike-slip movement, and comprises the E-W extensional region mainly concentrated along the Jucuaran-Intipuca Range. We propose the on-shore faults located near and parallel to the coast (Fig. 2) as southern boundary of this block, accumulating the deficit of dextral slip-rate up to the 12 $\mathrm{mm} \mathrm{yr}^{-1}$ of total movement between the CAFA and Caribbean blocks. Other authors (LaFemina et al., 2002; Funk et al., 2009; Alvarado et al., 2011) propose a fault located offshore as a bounding strike slip fault of a pull-apart basin. A third explanation for this missing movement could be the existence of ductile deformation of the crust. The western and eastern boundaries are not clearly defined and currently are subject to an open discussion. In the San Miguel segment, between the San Miguel volcano and the Gulf of Fonseca, the deformation is concentrated mainly to the south. We estimate a dextral strike-slip movement of $3 \pm 2 \mathrm{~mm} \mathrm{yr}^{-1}$ for this segment. We also estimate an extension of $5 \pm 2.5 \mathrm{~mm}$ $\mathrm{yr}^{-1}$ in E-W direction concentrated mainly along the Jucuaran-Intipuca Range and surroundings by the N-S and NE-SW normal faults. This extension is consistent with previous deformation studies based on morphotectonic analysis (Hernández-Moreno, 2011) and geodetic data (Alvarado et al., 2011 and Correa-Mora et al., 2009) that obtain an extension of $4 \mathrm{~mm} \mathrm{yr}^{-1}$ for this area. In the Berlin segment, between the Lempa River and San Miguel volcano, we estimate a dextral strike-slip movement of $7.5 \pm 3.5 \mathrm{~mm} \mathrm{yr}^{-1}$ concentrated mainly in Berlin segment. Taking this value into account, we detect a slip rate deficit of $\sim 4$ $\mathrm{mm} \mathrm{yr}^{-1}$ up to the $12 \mathrm{~mm} \mathrm{yr}^{-1}$ of movement between the CAFA and Caribbean blocks. It is possible that this missing movement could be accommodated in several NW-SE structures, not already studied, located to the south of the Berlin segment (Fig. 8).

The Central and Western blocks comprise the Lempa pull-apart and Central Graben, respectively, indicating that, at present, faults along the northern boundary of the graben are more active with an almost pure dextral strike-slip movement. Nevertheless, the southern faults are also active, albeit with a lower strike-slip rate and an oblique movement with a significant normal component. These faults located south of the Central graben could be responsible for the extensional component in the area. Both blocks are part of the depressed zone limited by the main structures of the ESFZ, known in the literature as Median Trough of El Salvador (Carr, 1976). In the Western block, between Coatepeque and Ilopango Calderas, deformation is distributed between the El Balsamo Range to the south and the Guaycume Fault to the north. This area is characterized by a dextral strike-slip 
movement of up to $11 \pm 3 \mathrm{~mm} \mathrm{yr}^{-1}$, mainly accumulated in Guaycume fault $\sim 9 \mathrm{~mm} \mathrm{yr}^{-1}$, with an extensional component of $4 \pm 2.5 \mathrm{~mm} \mathrm{yr}^{-1}$. This is consistent with the morphology and local structure of the Central graben extension (Lexa et al., 2011). In the Central block, between Ilopango Lake and the Lempa River, deformation is concentrated in a narrower band, characterized by an almost pure dextral strike-slip movement. We estimate a dextral strike-slip movement of $10 \pm 1 \mathrm{~mm} \mathrm{yr}^{-1}$ in the San Vicente segment. This movement is mainly attributed to San Vicente fault, $\sim 7 \mathrm{~mm} \mathrm{yr}^{-1}$. In the Lempa pull-apart a dextral strike-slip movement of $9 \pm 2 \mathrm{~mm} \mathrm{yr}^{-1}$ is accumulated, divided mainly between the northern and southern faults of pull-apart, suggesting slip-rates of $\sim 7 \mathrm{~mm} \mathrm{yr}^{-1}$ and $\sim 2 \mathrm{~mm} \mathrm{yr}^{-1}$, respectively. Also, we detected an extensional component with a maximum rate of $3 \pm 1.5$ $\mathrm{mm} \mathrm{yr}^{-1}$, which is consistent with the strain distribution within a pull-apart. It should be noted that there is insufficient data to confirm the slip rate of the fault system located to the south of these blocks, as well as to understand how the deformation is distributed in the western extreme of El Salvador and toward Guatemala in the Jalpatagua fault.

There are several geological and paleoseismological studies of some segments and faults of the ESFZ. Canora et al. (2014b), using geological and river offsets and paleoseismic analysis, estimate a slip rate for the central part of the ESFZ (San Vicente and Berlin segments) with an average value of $4.475 \pm 0.55 \mathrm{~mm} \mathrm{yr}^{-1}$. Canora et al. (2012) using paleoseismological studies propose a dextral strike-slip rate for the San Vicente segment with an average value of about $4.1 \pm 0.7 \mathrm{~mm} \mathrm{yr}^{-1}$ for the last $5.5 \mathrm{ka}$. Alonso-Henar et al. (2014), from morphometric analysis, suggest a maximum slip-rate of $4.6 \mathrm{~mm} \mathrm{yr}^{-1}$ for the Berlin segment. These values are lower than those obtained in this paper from geodetic data of these segments $(\sim 7 \mathrm{~mm}$ $\left.\mathrm{yr}^{-1}\right)$. The underestimation of the paleoseismological slip rates is expected, since these values do not correspond to the entire fault, but rather to a specific branch of the segment of the fault. On the other hand, the GPS slip rates represent an upper bound of the overall slip rate (e.g. Reilinger et al., 2006), since it has been assumed that all the measured deformations occur on the fault and no slip on secondary faults and/or internal (ductile) strain accumulation has been considered. On the other hand, Corti et al. (2005), using geological and geomorphological data, suggest $11 \mathrm{~mm} \mathrm{yr}^{-1}$ late Pleistocene-Holocene strike-slip motion on the El Salvador Fault Zone, which is in good agreement with the CAFA motion relative to the Caribbean plate obtained for the ESFZ from GPS data. 
It is expected that the locking depths of different faults of ESFZ are similar, since the crust must have similar rheologies and heat flows. However, it should be noted that our GPS network has a low density of stations near the traces to obtain accurate locking depths. Considering the data limitation, in general the analyzed faults are coupled with a locking depth between 4 and $9 \mathrm{~km}$. These values agree with the results obtained by other authors (Kikuchi and Yamanaka, 2001) and are consistent with the distribution of the aftershocks occurred after the February 2001 earthquake on San Vicente fault (Canora et al., 2010).

\subsection{Tectonic interpretation.}

The velocity and strain analysis along the ESFZ suggests that the boundary between the CAFA and the Caribbean block is a large shear zone in which deformation varies along the structure. We estimate that the movement between the two blocks is at least $\sim 12 \mathrm{~mm} \mathrm{yr}^{-1}$, according to other authors (e.g. Kobayashi et al., 2014). This movement is distributed between the different faults of the ESFZ in a different way from west to east (Figs. 5a-e and 8).

Our velocity field does not detect the existence of compressional deformations associated with the convergence between the Cocos and Caribbean plates. This is consistent with the low coupling in the Caribbean-Cocos subduction interface, as suggested by other authors (e.g. Álvarez-Gómez et al., 2008; Correa-Mora et al., 2009; Alvarado et al., 2011; Franco et al., 2012; Geirsson et al., 2015). However, our GPS network is located > $100 \mathrm{~km}$ from the trench, this presents a difficulty for the studies of the subduction zone earthquake cycle in this area.

Although this study does not address vertical deformation rates, the results obtained for the vertical velocities (see Fig. S4 in supplementary material) suggest that there is no clear uplift or subsidence trend in the ESFZ. This also agrees with the low coupling in the subduction zone along the Cocos-Caribbean interface in the El Salvador region (e.g. Álvarez-Gómez et al., 2008; Franco et al., 2012; Geirsson et al., 2015). Moreover, the values obtained are quite consistent with the ESFZ local tectonic structure, with slight subsidence in the extensional areas, as in the graben to the south of the Guaycume fault and the extensional zone of Jucuaran-Intipuca Range.

A significant increase in the velocity from east to west is observed in the forearc block, which is in agreement with the velocities observed by other authors in the zone (Kobayashi et al., 2014). This increase from east to west is consistent with the regional kinematics of the 
Chortis block (Fig. 1) (Rogers et al., 2007). The higher extension in the west combined with the pinning of the forearc block in Guatemala (Álvarez-Gómez et al., 2008) contributes to the strike-slip rate increasing from east to west in Salvador. This agrees with the hypothesis that the pull on the CAFA western edge is the main driver of the Salvadoran forearc motion, due the pinning of the CAFA to the North American plate at the diffuse triple junction (Lyon-Caen et al., 2006; Álvarez-Gómez et al., 2008; Franco et al., 2012). We propose the existence of two different drivers acting with different intensity in the Salvadoran and Nicaraguan forearc, the pinning of the CAFA to the northwest and the Cocos-Caribbean interaction to the southeast. This is consistent with the existence of the Fonseca basin (with particular sesimotectonic characteristics), that could be related to the transition of movement between the Nicaraguan and Salvadoran arcs. It is also important to note the change in the orientation of both forearcs in the Gulf of Fonseca, which could be the cause of the difference in the tectonic behavior of both forearcs.

\subsection{Seismic hazard implications.}

The results of this study can contribute to better estimates of seismic hazard, particularly the ground shaking associated with fault ruptures of the ESFZ segments. The obtained geodetic slip rate and recurrence intervals, combined with elapsed times deduced from historical seismicity data and paleoseismicity, may facilitate the estimates of seismic hazard using active faults and segments as independent sources rather than considering seismogenic zones with randomly distributed seismicity, as well as replacing Poisson models by timedependent models.

Table 2 lists the recurrence intervals obtained from the parameters calculated in this work that should be utilized to model the active faults in seismic hazard assessment. These new data contribute to the development of new hazards calculations. Although this would be the subject of future research, it can be expected that accelerations increase close and around the segments with higher slip rates, and that the probability of exceedance decreases in areas where the recurrent intervals approaches the elapsed time, regarding results of previous studies in the zone (Benito et al., 2010; Benito et al., 2012).

It is expected a hazard decrease close to the San Vicente segment of the ESFZ since this was the responsible for the $M_{w} 6.62001$ earthquake, and the estimated recurrence interval reaches 234 years, time necessary to accumulate the amount of elastic strain to produce a similar event. 
However, the Lempa segment (Apastepeque fault) is accumulating elastic strain through a strike-slip movement with a rate of $7 \pm 2 \mathrm{~mm} \mathrm{yr}^{-1}$, and there is no record of large earthquakes in this area at least in the last 100 years. Furthermore, the model of Coulomb Failure stress transferred by the 2001 event, significantly loaded this segment according to Martinez et al. (2004). It is expected that the seismic hazard in this area is higher than the obtained with the probabilistic methods using seismogenic zones commonly considered in the regulations.

Moreover, we should not discard an extreme but possible scenario that combine the ruptures of the San Vicente, Lempa, Berlin and San Miguel segments all together, which should involve a surface rupture length $>100 \mathrm{~km}$. Assuming a seismogenic depth of $10 \mathrm{~km}$, and the scale relationships of Stirling et al. (2008) this would produce a $M_{w}>7.0$ earthquake. Paleoseismic data obtained in previous works combined with historical seismicity data support this possibility (Canora et al., 2012; Canora et al., 2014a).

It would be advisable to quantify the expected ground motion linked to different earthquake scenarios associated with the different slip rates obtained in this work, which we propose as a future research line.

\section{Conclusions.}

The analysis of a new GPS data set in El Salvador confirms and quantifies the on-going tectonic activity of the El Salvador Fault Zone (ESFZ). The velocity and strain rate analyzed clearly indicate transtensional dextral strike-slip fault kinematics. The displacement pattern is typical of a locked strike-slip fault zone.

The velocity field analysis and slip rate distribution along the ESFZ suggest that the boundary between the Salvadoran forearc and Caribbean blocks is a deformation zone which varies along the fault zone. We estimate that the movement between the two blocks is at least of $\sim 12 \mathrm{~mm} \mathrm{yr}^{-1}$. This movement is distributed between faults or segments of the ESFZ in a different way from west to east. We propose a kinematic model with three main blocks; the Western, Central and Eastern blocks delimited by major faults. For the first time, we were able to provide a quantitative measure of the present-day horizontal geodetic slip rate of the main segments of ESFZ, ranging from $\sim 2 \mathrm{~mm} \mathrm{yr}^{-1}$ in the east segment to $\sim 8 \mathrm{~mm} \mathrm{yr}^{-1}$, in the west and central segments.

The observed GPS measurements confirm an increase of velocity from east to west within the forearc block, which is coherent with the regional kinematics of the Chortis block. We 
confirm an E-W extensional rate of $\sim 5 \mathrm{~mm} \mathrm{yr}^{-1}$ concentrated mainly along the JucuaranIntipuca Range and surrounding areas by the N-S and NE-SW normal faults. This extensional structure is part of the Fonseca basin, which could be related to the transition of movement between the Nicaraguan and Salvadoran arcs.

The GPS velocities obtained in this study complement and enhance the previous works by providing a higher spatial resolution of GPS data coverage in the area, and contribute to a better understanding of the kinematics of the ESFZ, which are all essential for increasing our knowledge of the seismogenic behavior of the ESFZ and for improving seismic hazard assessments in the region.

\section{Acknowledgments}

We thank all the individuals and institutions who contributed to the installation and observations of the ZFESNet network as well as the property owners who kindly gave their permission for the construction of the monuments. The GPS ZFESNet network in El Salvador is operated as collaborative efforts by Gerencia de Geología (DGOA-MARN) of El Salvador. We are grateful to the El Salvador army for logistical support in the project. This research was supported by the Universidad Politécnica de Madrid (Ayudas para la Realización de Actividades con América Latina), the Spanish Ministry of Science and Innovation, with the projects ASPERIDES (CGL2009-14405-C02-01) and INTERGEO (CGL2013-47412-C2-1-P), and the Spanish Agency for International Cooperation and Development (AECID), with the project Development of geological and seismological studies in El Salvador to seismic risk mitigation. Finally, we gratefully appreciate having at our disposal data from permanent stations by IGS, CORS, UNAVCO and some permanent stations in El Salvador and Honduras by Chuck DeMets. Figures were produced using Generic Mapping tools software (Wessel et al., 2013). We are grateful to Giorgi Khazaradze and an anonymous reviewer for their constructive comments that improved the original manuscript.

\section{References}

Alonso-Henar, J., Álvarez-Gómez, J.A. and Martínez-Díaz, J.J., 2014. Constraints for the recent tectonics of the El Salvador Fault Zone, Central America Volcanic Arc, from $\begin{array}{llll}\text { morphotectonic } & \text { analysis. } & \text { Tectonophysics, }\end{array}$ http://dx.doi.org/10.1016/j.tecto.2014.03.012

Alonso-Henar, J., Schreurs, G., Martinez-Díaz, J.J., Álvarez-Gómez, J.A. and Villamor, P., 2015. Neotectonic development of the El Salvador Fault Zone and implications for 
deformation in the Central America Volcanic Arc. Insights from 4D analogue modeling experiments. Tectonics, 34, 133-151. http://dx.doi.org/10.1002/2014TC003723.

Altamimi, Z., L. Métivier, and X. Collilieux, 2012. ITRF2008 plate motion model. J. Geophys. Res., 117, B07402. http://dx.doi.org/10.1029/2011JB008930.

Alvarado, D., DeMets, C., Tikoff, B., Hernández, D., Wawrzyniec, T.F., Pullinger, C., Mattioli, G., Turner, H.L., Rodríguez, M. and Correa-Mora, F., 2011. Forearc motion and deformation between El Salvador and Nicaragua: GPS, seismic, structural, and paleomagnetic observations. Lithosphere, 3(1), 3-21. http://dx.doi.org/10.1130/L108.1.

Álvarez-Gómez, J.A., 2009. Tectónica Activa y Geodinámica en el Norte de Centroamérica. (PhD thesis) Universidad Complutense de Madrid, Madrid, $227 \mathrm{pp}$.

Álvarez-Gómez, J.A., Meijer, P.T., Martínez-Díaz, J.J. and Capote, R., 2008. Constraints from finite element modeling on the active tectonics of northern Central America and the Middle America Trench, Tectonics, 27, TC1008. http://dx.doi.org/10.1029/2007TC002162.

Álvarez-Gómez, J. A., Gutiérrez, O. Q. G., Aniel-Quiroga, Í. and González, M., 2012. Tsunamigenic potential of outer-rise normal faults at the Middle America trench in Central America. Tectonophysics, 133-143. http://dx.doi.org/10.1016/j.tecto.2012.08.014.

Ambraseys, N.N. and Adams, R.D., 1996. Large-magnitude Central American earthquakes, 1898-1994. Geophys. J. Int. 127, 665 - 692. http://dx.doi.org/10.1111/j.1365246X.1996.tb04046.x.

Benito, B., Cepeda, J. M., and Martínez-Díaz, J. J., 2004. Analysis of the spatial and temporal distribution of the 2001 earthquakes in El Salvador. Geolog. Soc. Am. Special Papers, 375, 339-356. http://dx.doi.org/10.1130/0-8137-2375-2.339.

Benito, B., Lindholm, C., Camacho, E., Climent, Á., Marroquín, G., Molina, E., Rojas, W., Talavera, E., Escobar, J. J., Alvarado, G., Torres, Y. and Perez-Escalante, M., 2010. Amenaza sísmica en América Central. Entimema, Madrid, 371 pp.

Benito, B., Lindholm, C., Camacho, E., CLiment, Á., Marroquín, G., Molina, E., Rojas, W., Escobar, J.J., Talavera, E., Alvarado, G.E. and Torres, Y., 2012. A New Evaluation of Seismic Hazard for the Central America Region. Bull. Seism. Soc. Am., 102 (2), 504-523, http://dx.doi.org/ 10.1785/0120110015. 
Blewitt, G. and Lavallée, D., 2002. Effect of annual signals on geodetic velocity. J. Geophys. Res., 107(B7), ETG9-1-11. http://dx.doi.org/10.1029/2001JB000570.

Bommer, J. J., Benito, M. B., Ciudad-Real, M., Lemoine, A., López-Menjívar, M. A., Madariaga, R., ... and Rosa, H., 2002. The El Salvador earthquakes of January and February 2001: context, characteristics and implications for seismic risk. Soil Dynam. Earth. Eng., 22(5), 389-418. http://dx.doi.org/10.1016/S0267-7261(02)00024-6.

Brune, J. N., 1968. Seismic moment, seismicity, and rate of slip along major fault zones. J. Geophys. Res., 73(2), 777-784. http://dx.doi.org/10.1029/JB073i002p00777.

Burkart, B., and Self, S., 1985. Extension and rotation of crustal blocks in northern Central America and effect on the volcanic arc. Geology, 13(1), 22-26. http://dx.doi.org/10.1130/0091-7613(1985)13<22:EAROCB>2.0.CO;2.

Cáceres, D., Monterroso, D. and Tavakoli, B., 2005. Crustal deformation in northern Central America.

Tectonophysics,

404,

119-131.

http://dx.doi.org/10.1016/j.tecto.2005.05.008.

Cailleau, B., LaFemina, P. C., and Dixon, T. H., 2007. Stress accumulation between volcanoes: an explanation for intra-arc earthquakes in Nicaragua?. Geophys. J. Int., 169(3), 11321138. http://dx.doi.org/10.1111/j.1365-246X.2007.03353.x.

Canora, C., 2011. Análisis sismotectónico, neotectónico y paleosísmico de la zona de falla de El Salvador, Centro América. (PhD thesis) Universidad Complutense de Madrid, Madrid. $192 \mathrm{pp}$.

Canora, C., Martínez-Díaz, J.J., Villamor, P., Berryman, K., Álvarez-Gómez, J.A., Pullinger, C. and Capote, R., 2010. Geological and seismological analysis of the Mw 6.6 February, 13th 2001 El Salvador earthquake: Evidence for surface rupture and implications for seismic hazard. Bull. Seism. Soc. Am., 100(6), 2873-2890. http://dx.doi.org/10.1785/0120090377.

Canora, C., Villamor, P., Martínez-Díaz, J.J., Berryman, K.R., Álvarez-Gómez, J.A., Capote R. and Hernández, W., 2012. Paleoseismic analysis of the San Vicente segment of the El Salvador Fault Zone, El Salvador, Central America. Geol. Acta, 10(2), 103-123. http://dx.doi.org/10.1344/105.000001700.

Canora, C., Martínez-Díaz, J. J., Insua-Arévalo, J. M., Álvarez-Gómez, J. A., Villamor, P., Alonso-Henar, J. and Capote-Villar, R., 2014a. The 1719 El Salvador Earthquake: An M > 
7.0 Event in the Central American Volcanic Arc? Seism. Res. Lett, 85(4), 784-793. doi: http://dx.doi.org/10.1785/0220130150.

Canora, C., J.J. Martínez-Díaz, P. Villamor, A. Staller, K. Berryman, J.A. Álvarez-Gómez, R. Capote and M. Díaz., 2014b. Structural evolution of the El Salvador Fault Zone: an evolving fault system within a volcanic arc. J. Iber. Geol. 40 (3), 471-488. http://dx.doi.org/10.5209/rev_JIGE.2014.v40.n3.43559.

Carr, M.J., 1976. Underthrusting and Quaternary faulting in northern Central America, Geol. Soc. Am. Bull. 87, 825-829. http://dx.doi.org/10.1130/00167606(1976)87<825:UAQFIN>2.0.CO;2.

Correa-Mora, F., DeMets, C., Alvarado, D., Turner, H.L., Mattioli, G., Hernández, D., Pullinger, C., Rodríguez, M. and Tenorio, C., 2009. GPS-derived coupling estimates for Central America subduction zone and volcanic arc faults: El Salvador, Honduras and Nicaragua. Geophys. J. Int., 179(3), 1279-1291. http://dx.doi.org/10.1111/j.1365246X.2009.04371.x.

Corti, G., Carminati, E., Mazzarini, F. and Garcia, M.O., 2005. Active strike-slip faulting in EI Salvador, Central America. Geology 33 (12), 989-992. http://dx.doi.org/10.1130/G21992.1.

Dach, R., Hugentobler, U., Fridez, P. and Meindl M., 2007. Bernese GPS Software Version 5.0Documentation. Astronomical Institute, University of Berne, January, 640 pp.

DeMets, C., 2001. A new estimate for present-day Cocos-Caribbean plate motion: Implications for slip along the Central American volcanic arc. Geophys. Res. Lett., 28 (21), 4043-4046. http://dx.doi.org/10.1029/2001GL013518.

DeMets, C., Mattioli, G., Jansma, P., Rogers, R., Tenorio, C. and Turner, H.L., 2007. Present motion and deformation of the Caribbean plate: constraints from new GPS geodetic measurements from Honduras and Nicaragua. Spec. Papers-Geol. Soc. Am., 428, 21-36. http://dx.doi.org/doi:10.1130/2007.2428(02).

DeMets, C., Gordon, R. G. and Argus, D. F., 2010. Geologically current plate motions, Geophys. J. Int., 181 (1), 1-80. http://dx.doi.org/10.1111/j.1365-246X.2009.04491.x.

Dixon, T., Gonzalez, G., Katsigris, E., and Lichten, S., 1991. First epoch geodetic measurements with the Global Positioning System across the northern Caribbean plate boundary zone. J. Geophys. Res., $96 \quad$ (B2), 2397-2415. http://dx.doi.org/10.1029/90JB02003. 
Dixon, T. H., Miller, M., Farina, F., Wang, H. and Johnson, D., 2000. Present-day motion of the Sierra Nevada block and some tectonic implications for the Basin and Range province, North American Cordillera. Tectonics, 19 (1), 1-24. http://dx.doi.org/10.1029/1998TC001088.

Dow, J.M., Neilan, R.E. and Rizos, C., 2009. The International GNSS Service in a changing landscape of Global Navigation Satellite Systems. J. Geod., 83, 191-198. http://dx.doi.org/10.1007/s00190-008-0300-3.

Feigl, K. L., King, R. W. and Jordan, T. H., 1990. Geodetic measurement of tectonic deformation in the Santa Maria fold and thrust belt, California. J. Geophys. Res: Solid Earth, 95 (B3), 2679-2699. http://dx.doi.org/10.1029/JB095iB03p02679.

Feigl, K. L. and Thatcher, W., 2006. Geodetic observations of post-seismic transients in the context of the earthquake deformation cycle. Comptes Rendus Geoscience, 338(14), 1012-1028. http://dx.doi.org/10.1016/j.crte.2006.06.006.

Fernández, J., González-Matesanz, F., Prieto, J., Rodríguez-Velasco, G., Staller, A., AlonsoMedina, A. and Charco M., 2004. GPS monitoring in the N-W part of the volcanic island of Tenerife, Canaries, Spain: Strategy and results. Pure appl. Geophys., 161 (7), 13591377. http://dx.doi.org/10.1007/s00024-004-2509-2.

Franco A., Lasserre, C., Lyon-Caen, H., Kostoglodov, V., Molina, E., Guzmán-Speziale, M., Monterosso, D., Robles, V., Figueroa, C., Amaya, W., Barrier, E., Chiquin, L., Moran, S., Flores, O., Romero, J., Santiago, J. A., Manea, M. and Manea, V. C., 2012. Fault kinematics in northern Central America and coupling along the subduction interface of the Cocos Plate, from GPS data in Chiapas (Mexico), Guatemala and El Salvador. Geophys. J. Int. 189 (3), 1223-1236. http://dx.doi.org/10.1111/j.1365246X.2012.05390.x.

Funk, J., Mann, P., McIntosh, K. and Stephens, J., 2009. Cenozoic tectonics of the Nicaraguan depression, Nicaragua, and Median Trough, El Salvador, based on seismic-reflection profiling and remote-sensing data. Geol. Soc. Am. Bull., 121 (11-12), 1491-1521. http://dx.doi.org/10.1130/B26428.1.

Geirsson, H., LaFemina, P. C., DeMets, C., Hernandez, D. A., Mattioli, G. S., Rogers, R., ... and Tenorio, V., 2015. The 2012 August 27 Mw7. 3 El Salvador earthquake: expression of weak coupling on the Middle America subduction zone. Geophys. J. Int., 202(3), 16771689. http://dx.doi.org/10.1093/gji/ggv244. 
Graham, S. E., DeMets, C., DeShon, H. R., Rogers, Rodríguez, M., Strauch, W. Wiese, K. and Hernandez, D., 2012. GPS and seismic constraints on the $M=7.32009$ Swan Islands earthquake: implications for stress changes along the Motagua fault and other nearby faults. Geophys. J. Int., 190(3), 1625-1639. http://dx.doi.org/10.1111/j.1365246X.2012.05560.x.

Guzmán-Speziale M., Valdés-González, C., Molina, E. and Martín Gómez, J., 2005. Seismic activity along the Central America volcanic arc: Is it related to subduction of the Cocos plate? $\quad$ Tectonophysics, $400 \quad(1-4), \quad 241 \quad$ - 254. http://dx.doi.org/10.1016/j.tecto.2005.03.006.

Hanks, T. C. and Kanamori, H., 1979. A moment magnitude scale. J. Geoph. Res.: Solid Earth (1978-2012), 84(B5), 2348-2350. http://dx.doi.org/10.1029/JB084iB05p02348.

Hernández-Moreno, C., 2011. Análisis morfotectónico de las deformaciones cuaternarias de la cordillera de Jucuarán-Intipuca (EI Salvador). (Master thesis) Universidad Complutense de Madrid, Madrid. 54 pp.

Holohan, E. P., De Vries, B. V. W. and Troll, V. R., 2008. Analogue models of caldera collapse in strike-slip tectonic regimes. Bull. Volcan., 70(7), 773-796. http://dx.doi.org/10.1007/s00445-007-0166-x.

Kashani, I., Wielgosz, P. and Grejner-Brzezinska, D. A., 2004. On the reliability of the VCV Matrix: A case study based on GAMIT and Bernese GPS Software. GPS Sol., 8(4), 193199. http://dx.doi.org/10.1007/s10291-004-0103-9.

Kikuchi and Yamanaka, 2001. EIC Seismological Notes № 99. Earthquake Research Institute Tokyo. http://www.eri.u-tokyo.ac.jp/sanchu/Seismo_Note/index-e.html.

Kobayashi, D., P. LaFemina, H. Geirsson, E. Chichaco, A. A. Abrego, H. Mora, and E. Camacho, 2014. Kinematics of the western Caribbean: Collision of the Cocos Ridge and upper plate deformation, Geochem. Geophys. Geosyst., 15 (5), 1671-1683, http://dx.doi.org/10.1002/2014GC005234.

LaFemina, P. C., Dixon, T. H., and Strauch, W., 2002. Bookshelf faulting in Nicaragua. Geology, 30(8), 751-754. http://dx.doi.org/10.1130/00917613(2002)030<0751:BFIN>2.0.CO;2.

LaFemina, P., Dixon, T. H., Govers, R., Norabuena, E., Turner, H., Saballos, A., Mattioli, G., Protti, M. and Strauch, W., 2009. Fore-arc motion and Cocos Ridge collision in Central 
America. Geochem., Geophys., Geosyst., 10, Q05S14. http://dx.doi.org/10.1029/2008GC002181.

Letellier, T., Lyard, F., and Lefevre, F., 2004. The new global tidal solution: FES2004. In Proceeding of the Ocean Surface Topography Science Team Meeting, St. Petersburg, Florida, 4-6.

Lexa, J., Sebesta, J., Chavez, J. A., Hernandez, W. and Pecskay, Z., 2011. Geology and volcanic evolution in the southern part of the San Salvador Metropolitan Area. J. Geosciences, 56(1), 106-140. http://dx.doi.org/10.3190/jgeosci.088.

Lundgren, P., Protti, M., Donnellan, A., Heflin, M., Hernandez, E., and Jefferson, D., 1999. Seismic cycle and plate margin deformation in Costa Rica: GPS observations from 1994 to 1997. J. geophys. Res.: Solid Earth (1978-2012), 104(B12), 28915-28926. http://dx.doi.org/10.1029/1999JB900283.

Lyon-Caen, H., Barrier, E., Lasserre, C., Franco, A., Chiquin, L., Duquesnoy, T., Flores, O., Galicia, O., Luna, J., Molina, E., Porras, O., Requena, J., Robles, V., Romero, J. and Wolf, R., 2006. Kinematics of the North American-Caribbean-Cocos plates in Central America form new GPS measurements across the Polochic-Motagua fault system. Geophys. Res. Lett., 33, L19309. http://dx.doi.org/10.1029/2006GL027694.

McCaffrey, R., 1992. Oblique plate convergence, slip vectors, and forearc deformation. J. Geophys. Res., 97 (B6), 8905-8915. http://dx.doi.org/10.1029/92JB00483.

McCaffrey, R., 1996. Estimates of modern arc-parallel strain rates in fore arcs. Geology, 24, 27-30. http://dx.doi.org/10.1130/0091-7613(1996)024<0027:EOMAPS>2.3.CO;2.

Malfait, B.T., and M.G. Dinkelman, 1972. Circum-Caribbean tectonic and igneous activity and the evolution of the Caribbean Plate. Geol. Soc. Am. Bull., 83 (2), 251-272. http://dx.doi.org/10.1130/0016-7606(1972)83[251:CTAIAA]2.0.CO;2.

Martínez-Díaz, J.J., Álvarez-Gómez, J.A., Benito, M.B. and Hernández, D., 2004. Triggering of destructive earthquakes in El Salvador. Geology, 32 (1), 65-68. http://dx.doi.org/10.1130/G20089.1.

Mathieu, L., de Vries, B. V. W., Pilato, M., and Troll, V. R., 2011. The interaction between volcanoes and strike-slip, transtensional and transpressional fault zones: Analogue models and natural examples. J. Struct. Geol., 33(5), 898-906. http://dx.doi.org/10.1016/j.jsg.2011.03.003. 
Molnar, P., and Sykes, L. R., 1969. Tectonics of the Caribbean and Middle America regions from focal mechanisms and seismicity. Geol. Soc. Am. Bull., 80 (9), 1639-1684. http://dx.doi.org/10.1130/0016-7606(1969)80[1639:TOTCAM]2.0.CO;2.

Neill, A.E., 1996. Global mapping functions for the atmosphere delay at radio wavelength. J. Geophys. Res., 101 (B2), 3227-3246. http://dx.doi.org/10.1029/95JB03048.

Peraldo, G. and W. Montero, 1999. Sismología Histórica de América Central, Instituto Panamericano de Geografía e Historia, México, 513, 347 pp.

Petrunin, A. G. and Sobolev, S. V., 2008. Three-dimensional numerical models of the evolution of pull-apart basins. Phys. Earth Planet. Inter., 171(1-4), 387-399. http://dx.doi.org/10.1016/j.pepi.2008.08.017.

Reilinger, R., McClusky, S., Vernant, P., Lawrence, S., Ergintav, S., Cakmak, R., ... and Karam, G., 2006. GPS constraints on continental deformation in the Africa-Arabia-Eurasia continental collision zone and implications for the dynamics of plate interactions. J. Geoph. Res. Solid Earth, 111(B5). http://dx.doi.org/10.1029/2005JB004051.

Rodríguez, M., DeMets, C., Rogers, R., Tenorio, C. and Hernandez, D., 2009. A GPS and modelling study of deformation in northern Central America. Geophys. J. Int., 178(3), 1733-1754. http://dx.doi.org/10.1111/j.1365-246X.2009.04251.x.

Rogers, R. D., Mann, P. and Emmet, P. A., 2007. Tectonic terranes of the Chortis block based on integration of regional aeromagnetic and geologic data. Geol. Soc. Am. Spec. Papers, 428, 65-88. http://dx.doi.org/10.1130/2007.2428(04).

Savage, J.C. and Burford, R.O., 1973. Geodetic determination of relative plate motion in Central California, J. Geophys. Res., 78, 832-845. http://dx.doi.org/10.1029/JB078i005p00832.

Smith-Konter, B. R., Sandwell, D. T., and Shearer, P., 2011. Locking depths estimated from geodesy and seismology along the San Andreas Fault System: Implications for seismic moment release. J. Geophys. Res.: Solid Earth (1978-2012), 116(B6). http://dx.doi.org/10.1029/2010JB008117.

Snay, R.A. and Soler T., 2008. Continuously Operating Reference Station (CORS): History, applications, and future enhancements. J. Surv. Eng., 134(4), 95-104. http://dx.doi.org/10.1061/(ASCE)0733-9453(2008)134:4(95). 
Staller, A., 2014. Modelización de las deformaciones corticales en El Salvador (Centroamérica) mediante la integración de datos geodésicos (GPS), geológicos y sismológicos. (PhD thesis) Universidad Politécnica de Madrid, Madrid. 222 pp.

Staller, A., Martínez-Díaz, J.J., Benito, B., Hernández, D., Díaz, M., Pullinger, C., DeMets, C., Canora, C., Álvarez-Gómez, J.A. and Béjar, M., 2008. GPS network to study the evolution of the seismic cycle of stress and strain associated to the El Salvador Fault Zone. GeoTemas, 10, 1079-1082.

Stirling, M. W., Gerstenberger, M. C., Litchfield, N. J., McVerry, G. H., Smith, W. D., Pettinga, J. and Barnes, P., 2008. Seismic hazard of the Canterbury region, New Zealand: New earthquake source model and methodology. Bull. New Zeal. Nati. Soc. Earthquake Eng., 41 (2), 51-65.

Turner, H. L., LaFemina, P., Saballos, A., Mattioli, G. S., Jansma, P. E. and Dixon, T., 2007. Kinematics of the Nicaraguan forearc from GPS geodesy. Geophys. Res. Lett., 34(2). http://dx.doi.org/10.1029/2006GL027586.

Vernant, P., 2015. What can we learn from 20 years of interseismic GPS measurements $\begin{array}{lllll}\text { across strike-slip } & \text { 22-39. }\end{array}$ http://dx.doi.org/10.1016/j.tecto.2015.01.013.

Vigny, C., A. Socquet, C. Rangin, N. Chamot-Rooke, M. Pubellier, M.-N. Bouin, G. Bertrand, and M. Becker, 2003. Present-day crustal deformation around Sagaing fault, Myanmar, J. Geophys. Res., 108(B11), 2533. http://dx.doi.org/10.1029/2002JB001999.

Wallace L.M., Beavan J., McCaffrey R. and Darby D., 2004. Subduction zone coupling and tectonic block rotations in the North Island, New Zealand. J. Geophys. Res., 109, B12406. http://dx.doi.org/10.1029/2004JB003241.

Ward S.N., 1994. A multidisciplinary approach to seismic hazard in Southern California. Bull. Seism. Soc. Am., 84, 1293-1309.

Weinberg, R.E., 1992. Neotectonic development of western Nicaragua. Tectonics, 11(5), 1010-1017. http://dx.doi.org/10.1029/92TC00859.

Wessel, P., W. H. F. Smith, R. Scharroo, J. F. Luis, and F. Wobbe, 2013. Generic mapping tools: Improved version released. Eos Trans. AGU, 94, 409-410. http://dx.doi.org/10.1002/2013EO450001.

White, R. A., 1991. Tectonic implications of upper-crustal seismicity in Central America. Neotectonics of North America, 1, 323-338. 
White, R. A. and D. H. Harlow, 1993. Destructive upper-crustal earthquakes of Central America since 1900, Bull. Seismol. Soc. Am., 83, 1115 - 1142. 


\section{Table 1}

Table 1. Site positions (ITRF2008) and velocities relative to Caribbean reference frame. Uncertainties are standard errors. The errors given are 12 times the formal statistical errors. Ve positive to the east, $\mathrm{Vn}$ positive to the north.

\begin{tabular}{|c|c|c|c|c|c|c|}
\hline \multirow[b]{2}{*}{ GPS station } & \multicolumn{2}{|c|}{ Position } & \multirow[b]{2}{*}{$\begin{array}{l}\text { Total } \\
\text { Data }^{(a)}\end{array}$} & \multirow[b]{2}{*}{$\begin{array}{l}\Delta \mathrm{T}^{(\mathrm{b})} \\
\text { (years) }\end{array}$} & \multicolumn{2}{|c|}{ Velocities } \\
\hline & $\begin{array}{c}\text { Latitude } \\
\left({ }^{\circ} \mathrm{N}\right)\end{array}$ & $\begin{array}{c}\text { Longitude } \\
\left({ }^{\circ} \mathrm{E}\right)\end{array}$ & & & $\begin{array}{c}V e \\
\left(m m \mathrm{yr}^{-1}\right)\end{array}$ & $\begin{array}{c}V n \\
\left(m m \mathrm{yr}^{-1}\right)\end{array}$ \\
\hline $\operatorname{AIES}^{(1)}$ & 13.44726 & -89.05040 & 104 & 4.51 & $-11.5 \pm 0.5$ & $1.6 \pm 0.5$ \\
\hline AMAT & 13.40525 & -87.99889 & 5 & 4.51 & $-5.3 \pm 1.2$ & $0.8 \pm 1.2$ \\
\hline BT10 & 13.52896 & -88.50711 & 7 & 4.51 & $-11.8 \pm 1.2$ & $-0.2 \pm 1.2$ \\
\hline CABA & 13.72774 & -88.67700 & 6 & 4.51 & $-2.4 \pm 1.2$ & $1.5 \pm 1.2$ \\
\hline CARM & 13.72650 & -88.89847 & 6 & 4.51 & $-2.2 \pm 1.2$ & $1.9 \pm 1.2$ \\
\hline CARR & 13.66923 & -88.72772 & 11 & 4.51 & $-3.3 \pm 1.2$ & $1.2 \pm 1.2$ \\
\hline CEGD & 13.93950 & -88.90170 & 7 & 4.51 & $-1.6 \pm 1.2$ & $1.7 \pm 1.2$ \\
\hline $\mathrm{CH} 15$ & 13.62243 & -88.56115 & 24 & 4.51 & $-6.1 \pm 1.2$ & $1.5 \pm 1.2$ \\
\hline CHET 40526M001*(1) & 18.49528 & -88.29922 & 105 & 4.51 & $-18.8 \pm 0.5$ & $-5.6 \pm 0.5$ \\
\hline CNR1 ${ }^{(1)}$ & 13.67044 & -89.28901 & 80 & 3.52 & $-9.3 \pm 0.5$ & $1.4 \pm 0.5$ \\
\hline CSJO & 13.48650 & -88.38608 & 5 & 4.51 & $-6.7 \pm 2.4$ & $1.4 \pm 1.2$ \\
\hline ELEN 40902S001* (1) & 16.91606 & -89.86761 & 27 & 1.47 & $-21.0 \pm 2.4$ & $-5.5 \pm 1.2$ \\
\hline GUAT 40901S001* ${ }^{(1)}$ & 14.59040 & -90.52018 & 60 & 2.46 & $-4.9 \pm 0.5$ & $-1.0 \pm 0.5$ \\
\hline GUAY & 13.84108 & -89.16230 & 8 & 3.52 & $-0.9 \pm 2.4$ & $3.1 \pm 2.4$ \\
\hline ICHA & 13.56028 & -88.71624 & 6 & 4.51 & $-8.4 \pm 1.2$ & $3.0 \pm 1.2$ \\
\hline JUCU & 13.25287 & -88.24958 & 5 & 4.51 & $-9.5 \pm 1.2$ & $2.8 \pm 1.2$ \\
\hline LOLO & 13.55892 & -88.36851 & 10 & 4.51 & $-2.3 \pm 1.2$ & $1.1 \pm 1.2$ \\
\hline LPIN & 13.68044 & -87.91948 & 6 & 4.51 & $-3.1 \pm 2.4$ & $0.8 \pm 1.2$ \\
\hline LSSJ & 13.37803 & -88.19795 & 5 & 4.51 & $-11.5 \pm 2.4$ & $1.1 \pm 1.2$ \\
\hline MANA & 12.14894 & -86.24899 & 106 & 4.51 & $-6.7 \pm 0.5$ & $2.2 \pm 0.5$ \\
\hline MIGL & 13.52857 & -88.15003 & 15 & 4.51 & $-4.1 \pm 1.2$ & $0.5 \pm 1.2$ \\
\hline MNGO & 13.96509 & -89.19742 & 3 & 3.52 & $-0.2 \pm 2.4$ & $2.0 \pm 2.4$ \\
\hline NONU & 13.57408 & -88.95202 & 7 & 4.51 & $-10.7 \pm 1.2$ & $2.7 \pm 1.2$ \\
\hline OPAC & 13.72180 & -88.36670 & 5 & 4.51 & $-2.5 \pm 2.4$ & $3.0 \pm 2.4$ \\
\hline OSIC & 13.81387 & -88.14565 & 6 & 4.51 & $-2.9 \pm 1.2$ & $1.3 \pm 1.2$ \\
\hline PASA & 13.59177 & -87.83222 & 6 & 4.51 & $-4.0 \pm 1.2$ & $0.8 \pm 1.2$ \\
\hline PLAY & 13.79323 & -89.34524 & 5 & 3.52 & $-7.3 \pm 2.4$ & $2.3 \pm 2.4$ \\
\hline PRUS & 13.34709 & -88.60539 & 6 & 4.51 & $-9.1 \pm 1.2$ & $2.2 \pm 1.2$ \\
\hline RIOG & 13.82395 & -88.57777 & 5 & 3.52 & $-2.8 \pm 2.4$ & $-0.2 \pm 2.4$ \\
\hline SAIN & 13.32485 & -87.81526 & 6 & 4.51 & $-4.3 \pm 1.2$ & $1.2 \pm 1.2$ \\
\hline SBAR & 13.63394 & -88.35418 & 5 & 4.51 & $-2.9 \pm 1.2$ & $1.6 \pm 1.2$ \\
\hline SCAR & 13.63830 & -88.08294 & 5 & 4.51 & $-2.3 \pm 1.2$ & $1.0 \pm 1.2$ \\
\hline SNJE ${ }^{(1)}$ & 13.86825 & -89.60069 & 104 & 4.51 & $-6.7 \pm 0.5$ & $0.7 \pm 0.5$ \\
\hline SSIA 41401S001* (1) & 13.69708 & -89.11660 & 106 & 4.51 & $-4.2 \pm 0.5$ & $0.3 \pm 0.5$ \\
\hline SVIC & 13.63035 & -88.78718 & 9 & 4.51 & $-6.1 \pm 1.2$ & $3.4 \pm 1.2$ \\
\hline TACA & 13.96998 & -89.35361 & 5 & 3.52 & $-3.9 \pm 2.4$ & $1.3 \pm 2.4$ \\
\hline TEG1 41101S002 ${ }^{(1)}$ & 14.09007 & -87.20565 & 101 & 4.51 & $-3.6 \pm 0.5$ & $-2.0 \pm 0.5$ \\
\hline USUL & 13.37992 & -88.48417 & 10 & 4.51 & $-10.1 \pm 1.2$ & $-0.3 \pm 1.2$ \\
\hline VIEJ & 13.51490 & -88.98836 & 3 & 3.52 & $-11.9 \pm 2.4$ & $2.0 \pm 2.4$ \\
\hline VMIG $^{(1)}$ & 13.39615 & -88.30464 & 102 & 4.51 & $-7.9 \pm 0.5$ & $1.4 \pm 0.5$ \\
\hline
\end{tabular}

(a) Number of occupations.

(b) Time span of observations.

(1) Continuous GPS site.

* Sites used to define the reference frame. 


\section{Table 2}

Table 2. Best-fit fault parameters (locking depth, far field velocity and rms) from elastic dislocation model. Geodetic slip rates estimated from GPS velocities and Earthquake Moment Magnitudes $\left(M_{w}\right)$ and Recurrence Intervals (RI) derived from geodetic slip rates of the major segments and faults of the El Salvador Fault Zone analyzed in this study.

\begin{tabular}{|c|c|c|c|c|c|c|c|c|}
\hline \multirow{2}{*}{ Segment } & \multirow{2}{*}{ Fault } & \multirow{2}{*}{$\begin{array}{l}\text { Length } \\
(\mathbf{k m})\end{array}$} & \multicolumn{2}{|c|}{ Best-fit parameters } & \multicolumn{2}{|c|}{$\begin{array}{c}\text { Geodetic slip- } \\
\text { rate }\left({ }^{*}\right) \\
\left.(\mathrm{mm} \mathrm{yr})^{-1}\right)\end{array}$} & \multirow{2}{*}{$M_{w}^{(1)}$} & \multirow{2}{*}{$\begin{array}{l}\mathrm{RI}^{(2)} \\
(\mathrm{yr})\end{array}$} \\
\hline & & & $\begin{array}{l}\text { Locking } \\
\text { depth } \\
(\mathrm{km})\end{array}$ & $\begin{array}{cc}\begin{array}{c}\text { Far field } \\
\text { velocity } \\
\left.(\mathrm{mm} \mathrm{yr})^{-1}\right)\end{array} & \left(\mathrm{mm} \mathrm{yr}^{-1}\right) \\
\end{array}$ & strike & normal & & \\
\hline West & $\begin{array}{c}\text { Guaycume } \\
\text { Southern }\end{array}$ & $\begin{array}{c}36 \\
\sim 9.4 \\
\end{array}$ & $5 ?$ & $8 \quad 1.09$ & $\begin{array}{c}9 \pm 3 \\
2 ? \pm 0.5\end{array}$ & $4 \pm 2.5$ & 6.9 & 313 \\
\hline San Vicente & San Vicente & 21 & 8 & 12 & $7 \pm 1$ & & 6.6 & 234 \\
\hline Lempa & $\begin{array}{c}\text { Apastepeque } \\
\text { Southern }\end{array}$ & $\begin{array}{c}15 \\
\sim 7.6 \\
\end{array}$ & 6 & 1.38 & $\begin{array}{c}7 \pm 2 \\
2 ? \pm 2 \\
\end{array}$ & $3 \pm 1.5$ & 6.4 & 167 \\
\hline Berlin & & 32.8 & 9 & 1.31 & $\begin{array}{c}7.5 \pm \\
3.5 \\
\end{array}$ & & 6.9 & 342 \\
\hline San Miguel & & 47.7 & 4 & 0.52 & $3 \pm 2$ & & 7.1 & 1242 \\
\hline
\end{tabular}

$\left(^{*}\right)$ Values followed by question marks are an approximation which are obtained with few data, with high uncertainty or deduced by extrapolation. Positive values indicate dextral shear and extension.

(1) $M_{w}=4.18+2 / 3 \log (W)+4 / 3 \log (L)$ (Stirling et al., 2008) in kilometers. Mw, moment magnitude; W, seismogenic width $(10 \mathrm{~km})$; L, surface rupture length $(\mathrm{km})$.

(2) $\mathrm{RI}=\mathrm{Mo} / \mathrm{Mo} ; \log \mathrm{Mo}=16.1+1.5 \mathrm{M}_{\mathrm{w}}$ (Hanks and Kanamori, 1979); $\dot{M} \mathrm{o}=\mu \mathrm{As}$ (Brune, 1968). Mo, seismic moment (dyn.cm); Mo, seismic moment rate (dyn·cm/yr); $\mu$, average shear modulus $\left(3 \times 10^{11} \mathrm{dyn} / \mathrm{cm}^{2}\right)$; A, fault rupture area; s, slip rate; RI, Recurrence interval (in years). 


\section{Figure 1}

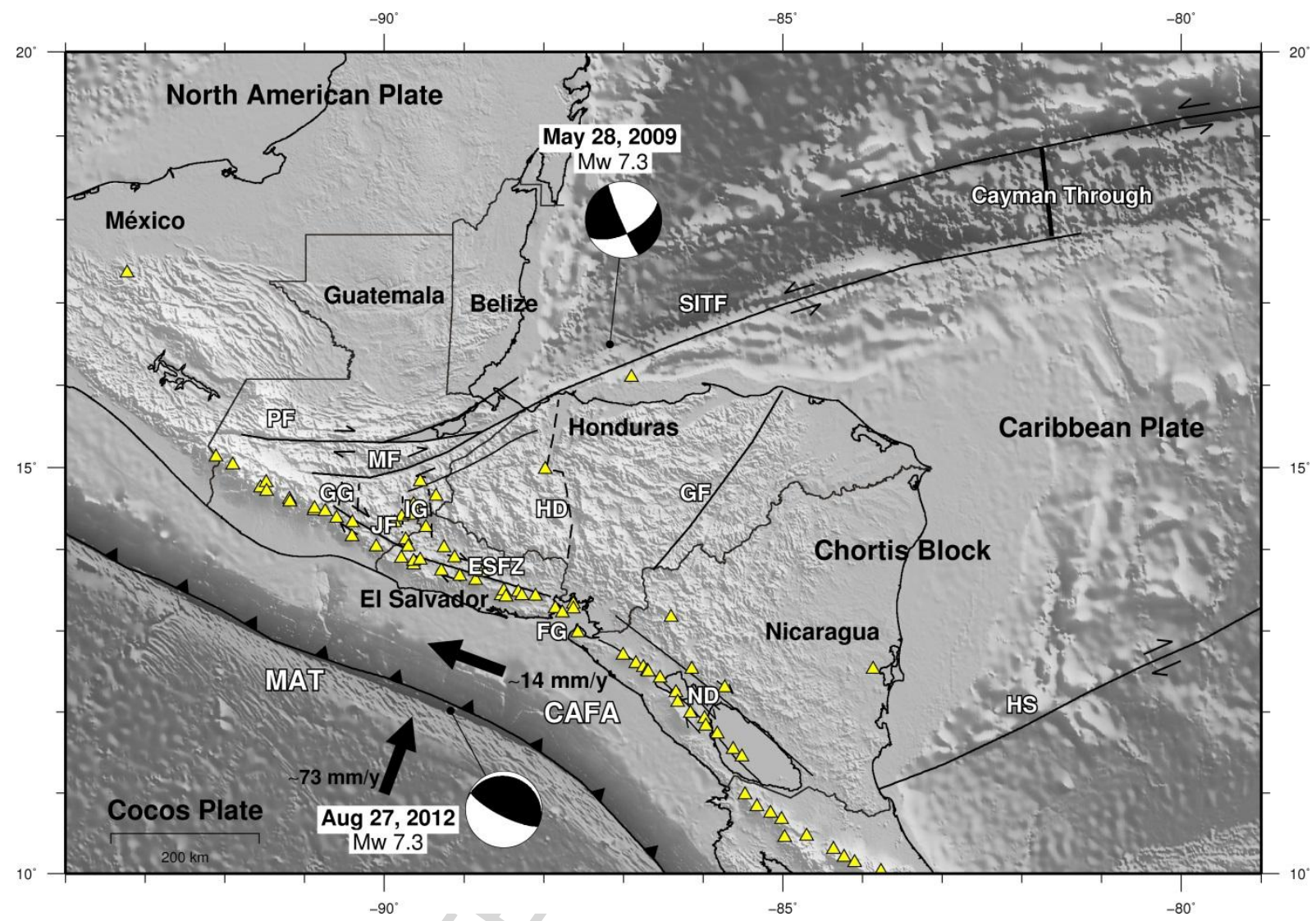

Fig. 1. Tectonic setting of northern Central America. Black vectors indicate relative rate and azimuth between Cocos and Caribbean plates (DeMets et al., 2010) and CAFA motion relative to Caribbean plate. Orange triangles show the position of volcanoes. Focal mechanisms and earthquake locations are for the 2009 May 28 and 2012 August 27 earthquakes from the Global CMT catalogue (Dziewonski et al., 1981). Abbreviations: CAFA Central American forearc, GG - Guatemala Graben, IG - Ipala Graben JF - Jalpatagua Fault, ESFZ - El Salvador Fault Zone, HD - Honduras Depression, ND - Nicaraguan Depression, FG Gulf of Fonseca, SITF - Swan Islands Transform Fault, PF - Polochic Fault, MF - Motagua Fault, HS - Hess Scarpment, GF - Guayapé Fault, MAT - Mid-American Trench. 
Figure 2

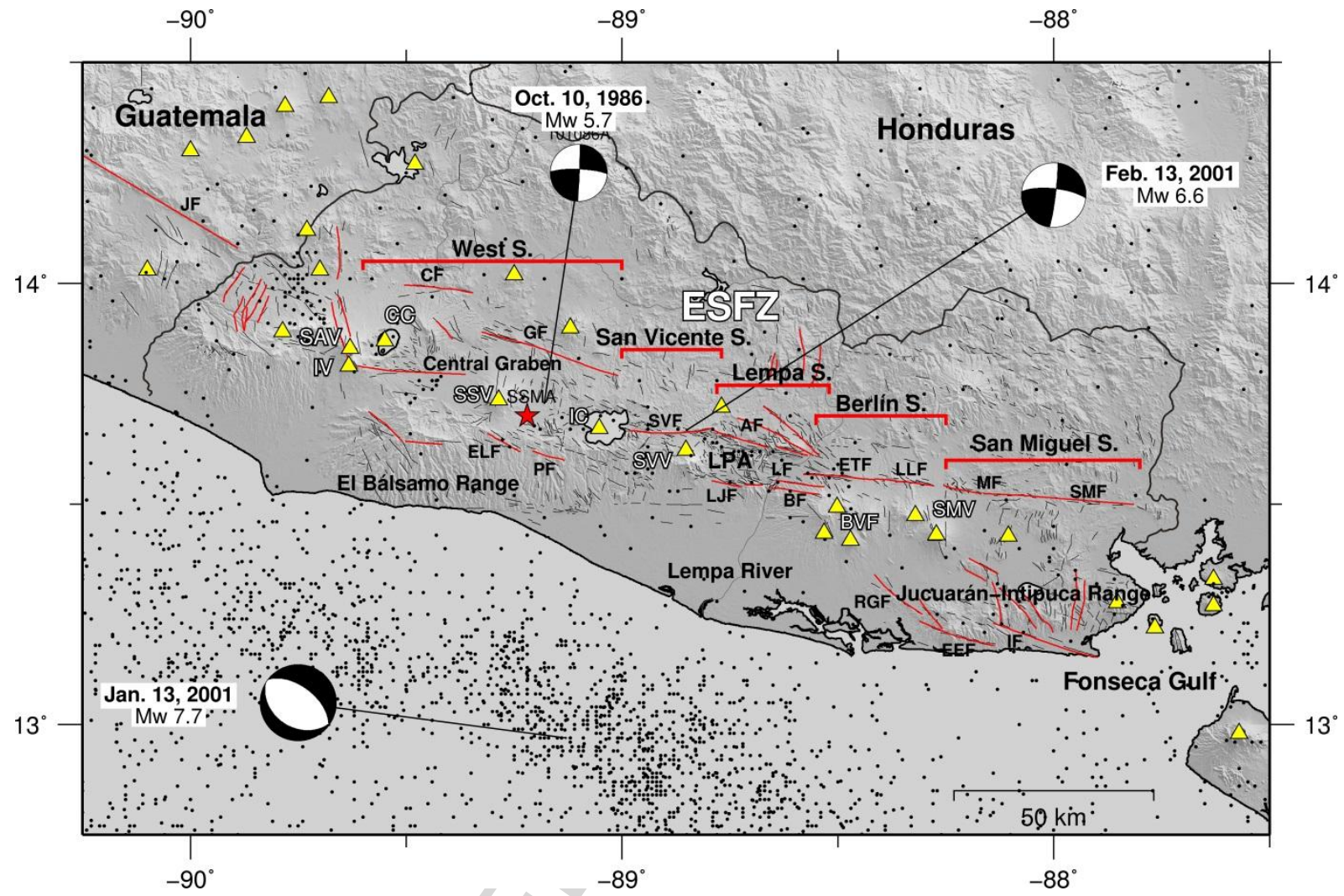

Fig. 2. Fault map of El Salvador with the main segments of the El Salvador Fault Zone. Red bold lines outline main active faults and thin black lines outline faults, extracted from Canora et al., 2012. Orange triangles show volcanoes. Black dots show instrumental seismicity $\left(M_{w}\right.$ $>$ 4, period 1976-2012) from Benito et al., 2010 catalogue. Focal mechanisms are for the 1986 October 10, 2001 January 13 and February 13 earthquakes from the Global CMT catalogue (Dziewonski et al., 1981). Abbreviations are the following: CF - Comecayo fault, GF - Guaycume fault, SVF - San Vicente fault, AF - Apastepeque fault, ETF - El Triunfo fault, LLF - Lolotique fault, MF - Moncagua fault, SMF - San Miguel fault, ELF - El Limón fault, PF Panchimalco fault, LJF - La Joya fault, BF - Berlin fault, LF - Lempa fault, RGF - Río Grande fault, EEF - El Espino fault, IF - Intipuca fault, JF - Jalpatagua fault, SAV - Santa Ana volcano, CC - Coatepeque caldera, IV - Izalco volcano, SSV - San Salvador volcano, IC - Ilopango caldera, SVV - San Vicente volcano, BVF - Berlin volcano field, SMV - San Miguel volcano, MASS - San Salvador Metropolitan Area, LPA - Lempa pull-apart, ESFZ - El Salvador Fault Zone. 
Figure 3

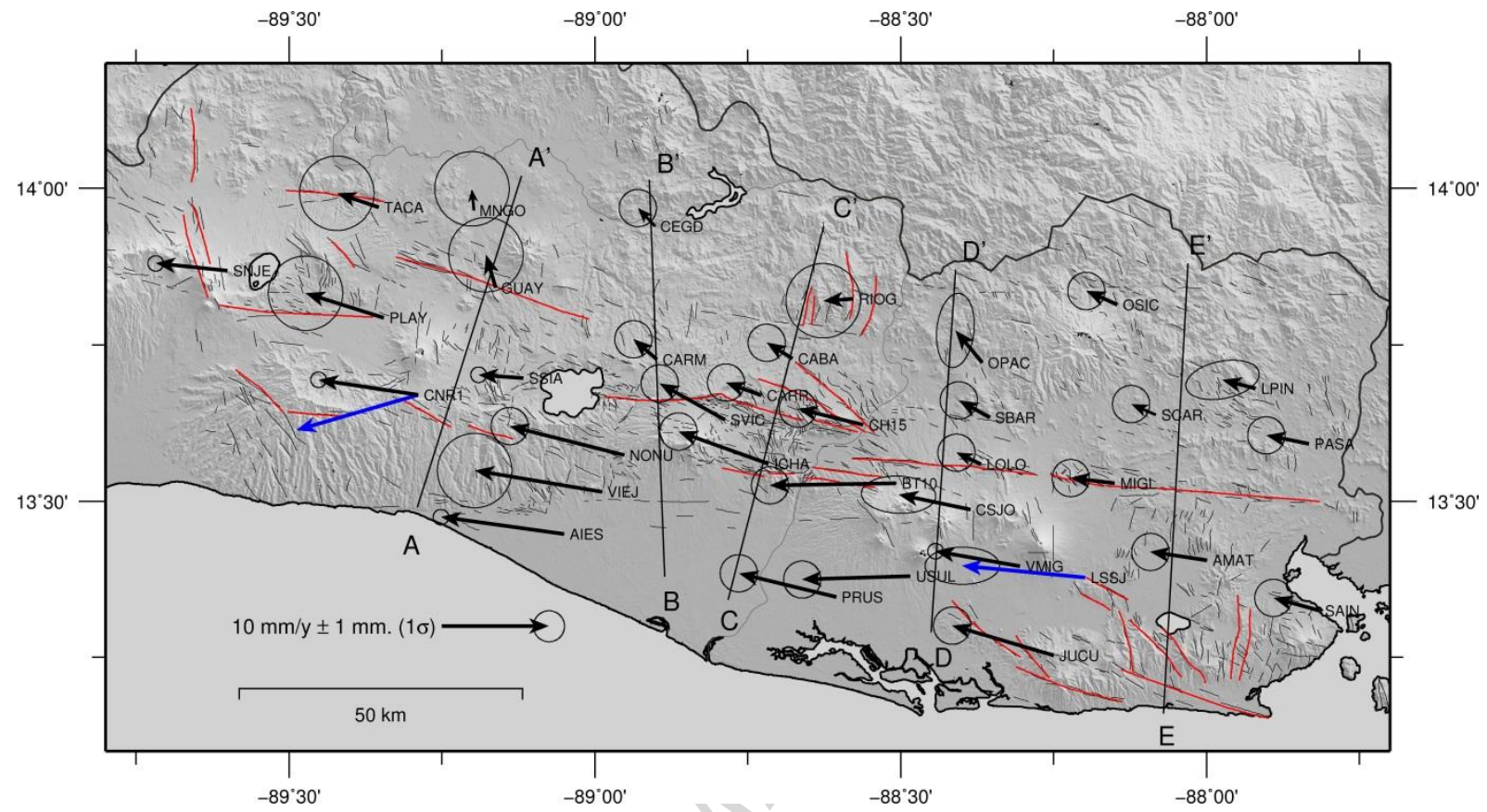

Fig. 3. ZFESNet GPS horizontal velocity field (black vectors) in Caribbean plate reference frame with $65 \%$ confidence error ellipses. Blue vectors show the anomalous velocities of the LSSJ and CNR1 stations, in the 2007-2012 period. Red bold lines outline main active faults of the ESFZ. Thin black lines outline the faults from Canora et al., 2012. Black lines show transverse profiles $\left(A-A^{\prime}, B-B^{\prime}, C-C^{\prime}, D-D^{\prime}\right.$ and $\left.E-E^{\prime}\right)$ used in Fig. 5. 


\section{Figure 4}

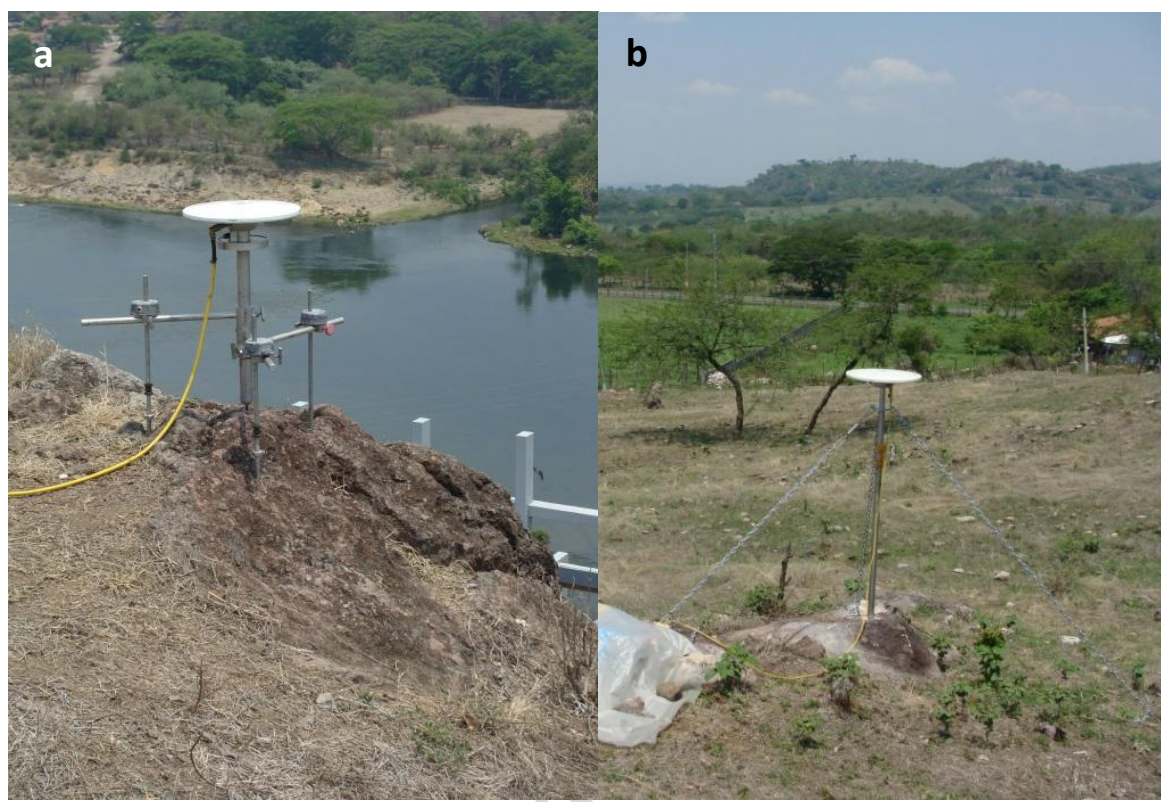

Fig. 4. Types of antenna mounts used in ZFESNet observation. a) $0.550 \mathrm{~m}$ fixed-height spike mount. b) $1.127 \mathrm{~m}$ levelled fixed-high pole. 


\section{Figure 5}

Distance along the profile $(\mathrm{km})$

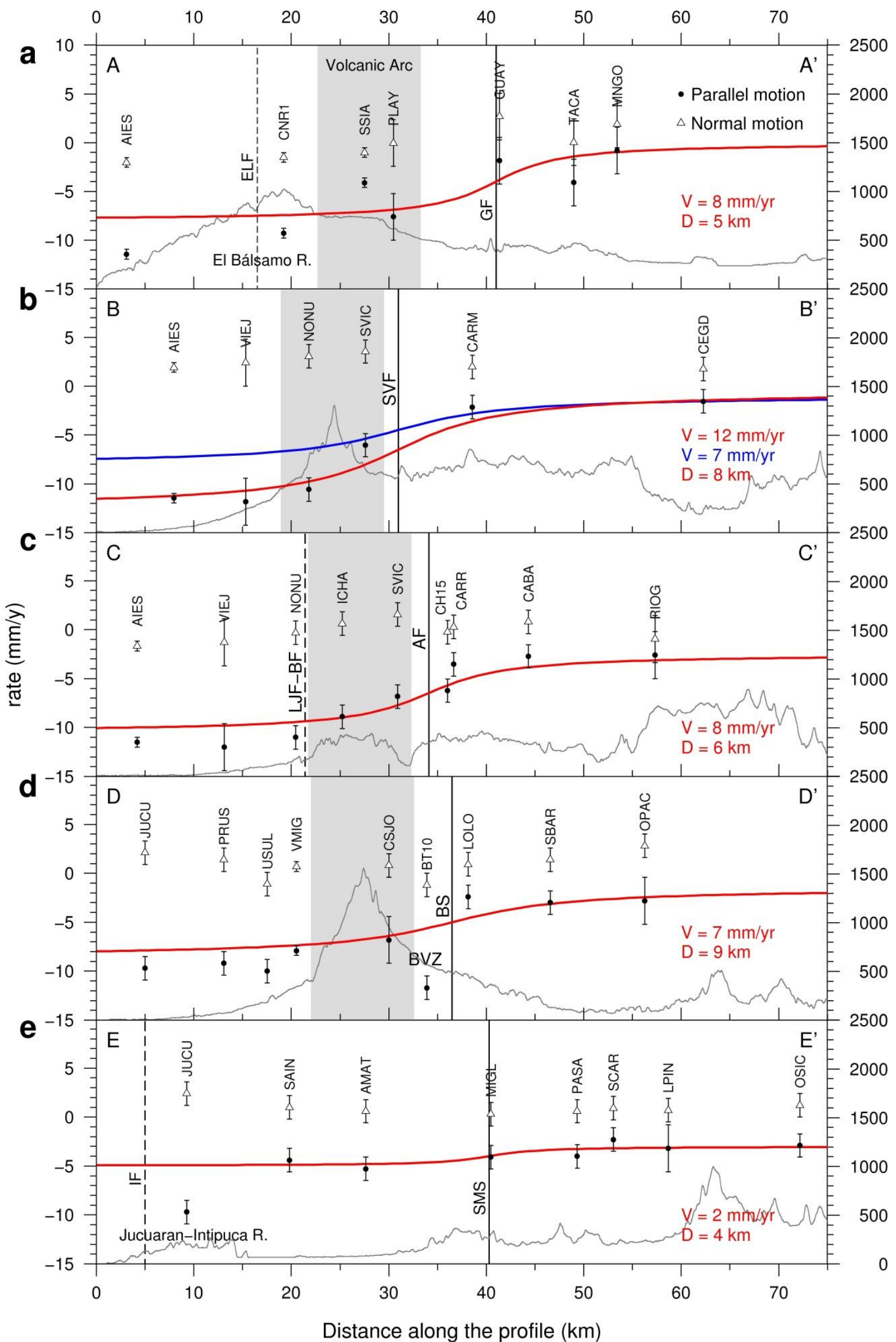

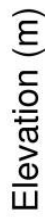


Fig. 5. Topography and Caribbean GPS velocities projected along 5 profiles show in Fig. 3 . Profile-parallel velocity components (black circles) and profile-normal velocity components (open triangles) with one standard error bar are plotted versus distance along profile. Red solid curved lines show the best-fit strain accumulation model for each modelled fault. The best fit parameters, locking depth (D) and far field velocity (V), are indicated in each profile. Blue solid curved line in profile B-B' shows the best-fit strain model excluding AIES, VIEJ and NONU stations, also in blue is shown the far field velocity field (V) obtained for this model. Vertical black lines show location of the modelled faults. Vertical dashed lines show location of other active faults taken into account in this study. Volcanic arc area is shaded. GF Guaycume fault, ELF - El Limón fault, SVF - San Vicente fault, AF - Apastepeque fault, LF-BF - La Joya and Berlin faults, BS - Berlin segment, SMS - San Miguel segment, IF - Intipuca fault, BVZ - Berlin volcanic zone. 
Figure 6

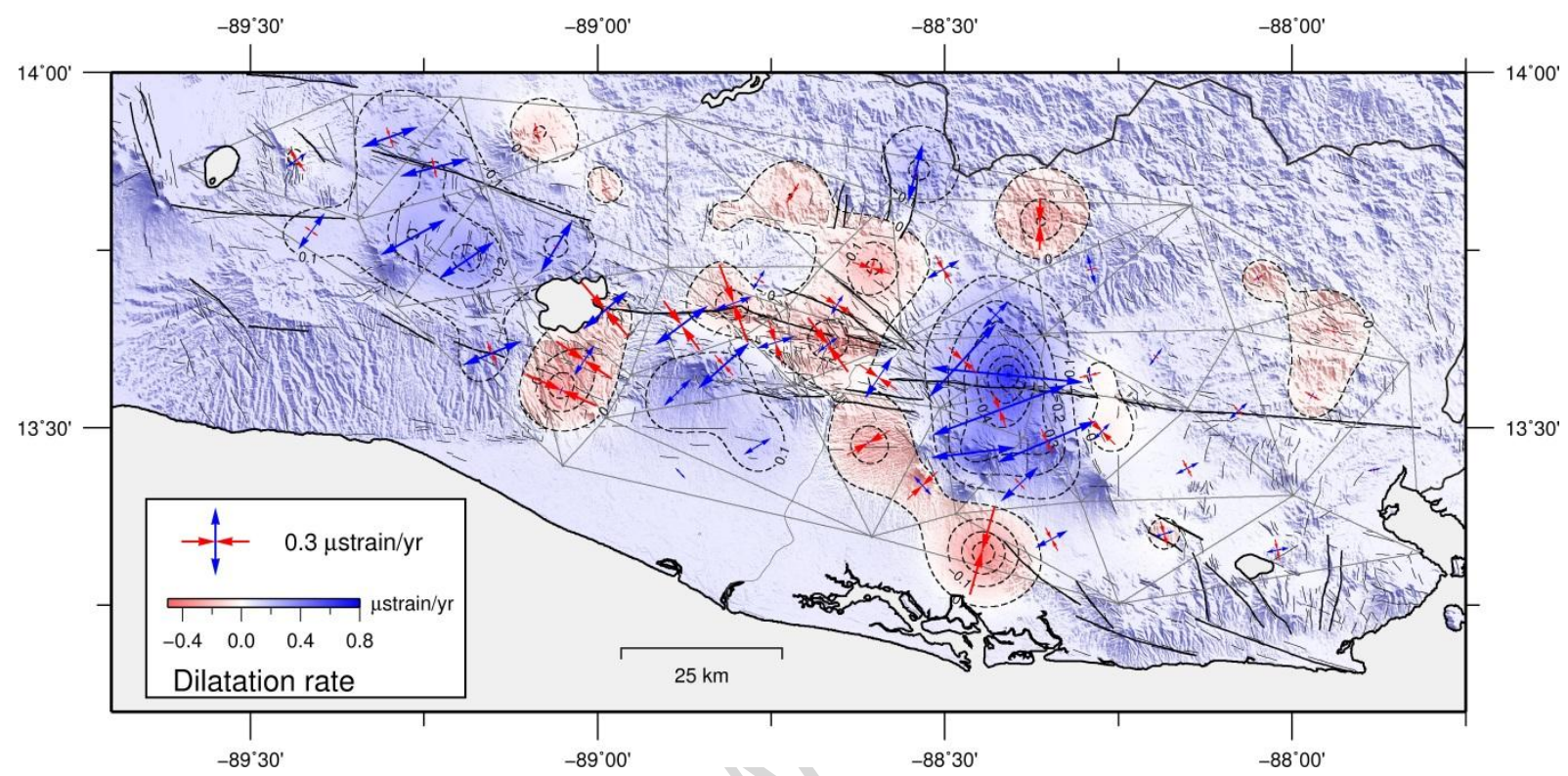

Fig. 6. Dilatation rate field (see colorbar) and strain rates in the ZFES calculated from interseismic velocities using Delaunay triangulation (in grey). Vectors show principal axes of the horizontal strain rate tensors. Inward pointing arrows depict compression (in red), outward pointing arrows depict extension (in blue). Negative values of dilatation rate indicate compression (in red) and positive values extension (in blue). Black lines outline main active faults. 
Figure 7

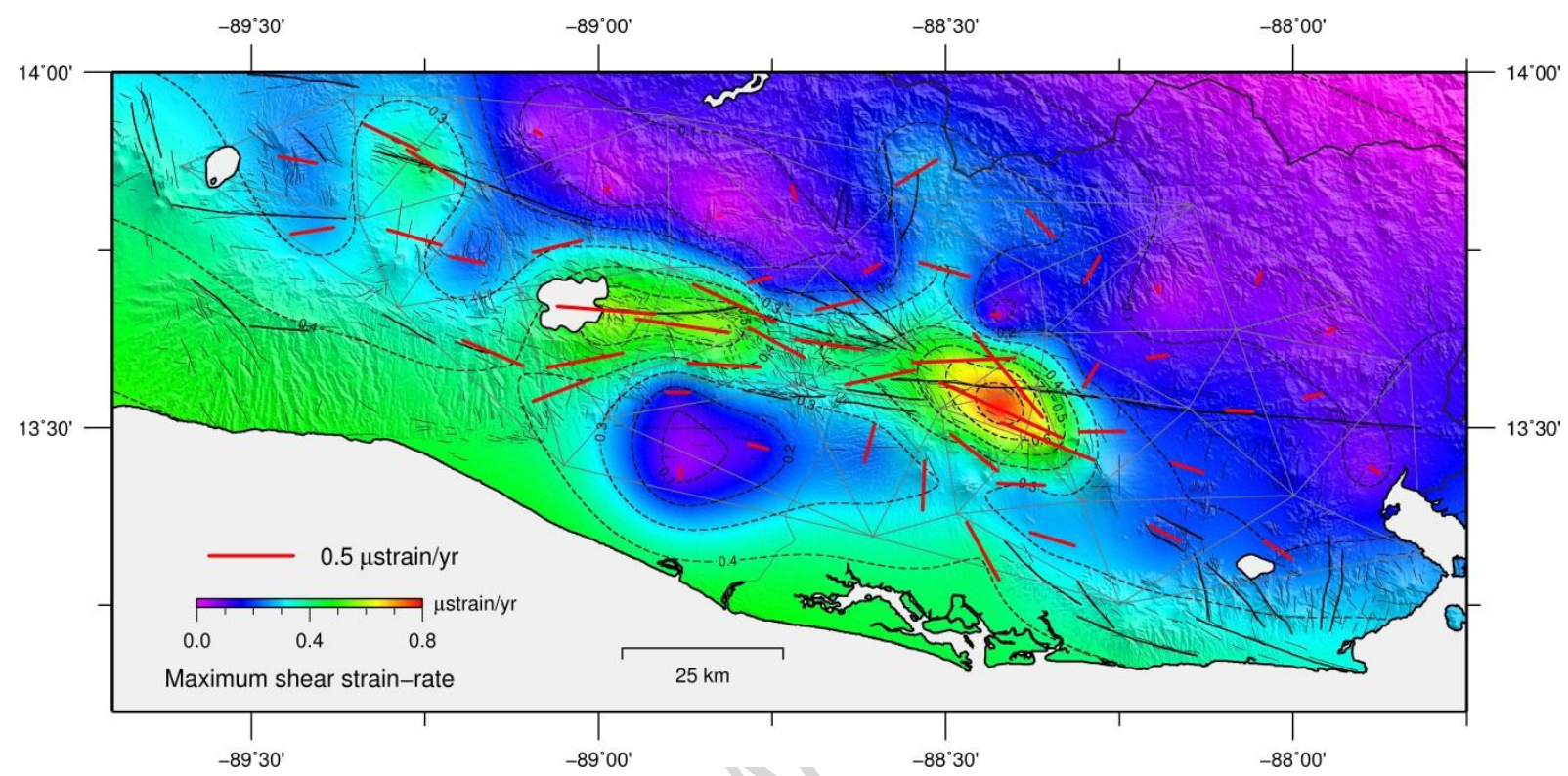

Fig. 7. Maximum shear strain rate field (see colorbar) in the ZFES calculated from interseismic velocities using Delaunay triangulation (in grey). Bold red lines show the orientation of the right-lateral shear strain rate within the triangle. Thin black lines outline main active faults. 


\section{Figure 8}

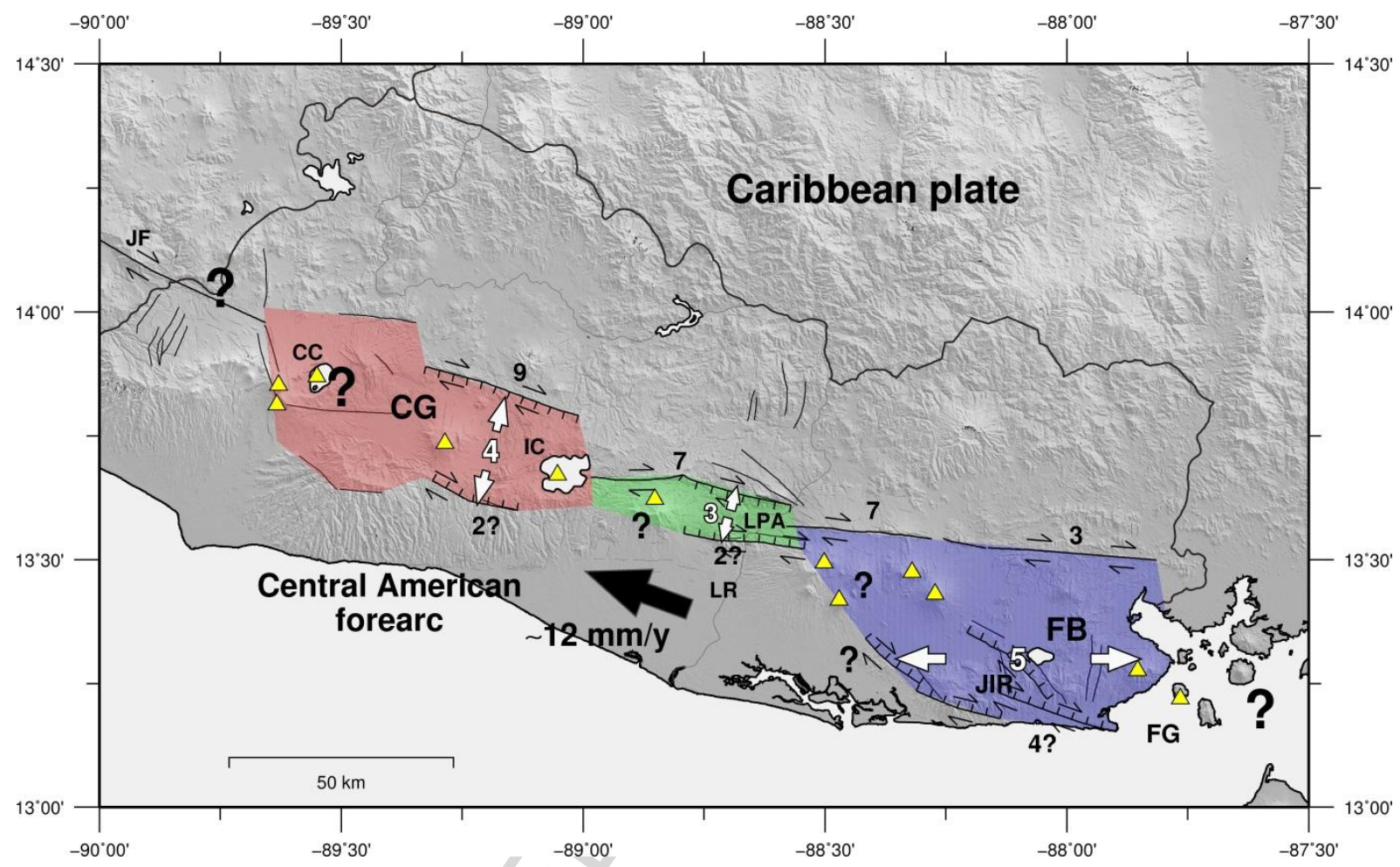

Fig. 8. Kinematic model of the ESFZ, showing the three main blocks: West block (in red), Central block (in green) and East block (in blue). Slip-rates in black show dextral shear

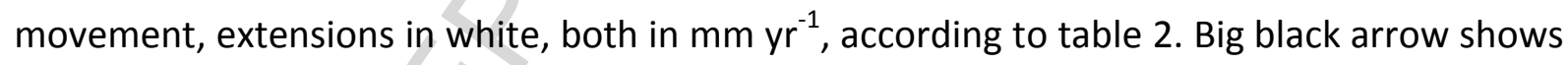
the direction of movement of the Salvadoran forearc. White arrows show extension. Values followed by question marks are an approximation which were obtained with few data, with high uncertainty or deduced by extrapolation. Question marks indicate zones without data and/or enough information to know the current strain distribution. Orange triangles show the positions of main volcanoes. Central and Western blocks form the Median Trough of El Salvador. CC-Coatepeque Caldera, IC-Ilopango Caldera, LPA - Lempa pull-apart, LR - Lempa River, FG - Gulf of Fonseca, FB - Fonseca basin, JIR - Jucuaran-Intipuca Range, CG - Central graben, JF - Jalpatagua fault. 


\section{Highlights}

- New geodetic data to understand the current kinematic of the El Salvador Fault Zone (ESFZ).

- Novel geodetic slip rate estimation for the largest active faults of El Salvador. The measured values range from $9 \mathrm{~mm} \mathrm{yr}^{-1}$ to $2 \mathrm{~mm} \mathrm{yr}^{-1}$.

- GPS velocities are consistent with the pinning model of the Central America Forearc (CAFA) to the North American plate. 